\title{
Serum levels of fibroblast growth factor-21 are increased in chronic and acute renal dysfunction
}

\author{
Dissertation \\ zur Erlangung des akademischen Grades \\ Dr. med. \\ an der Medizinischen Fakultät \\ der Universität Leipzig
}

eingereicht von:

Janka Hindricks

geboren am 05. August 1986 in Münster (Westf.)

angefertigt an der:

Klinik und Poliklinik für Endokrinologie und Nephrologie

Universität Leipzig

Betreuer:

Prof. Dr. med. habil. Mathias Faßhauer

Beschluss über die Verleihung des Doktorgrades vom: 06.10.2015 
Martina Hindricks gewidmet 


\section{Table of Contents}

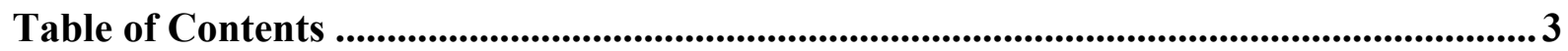

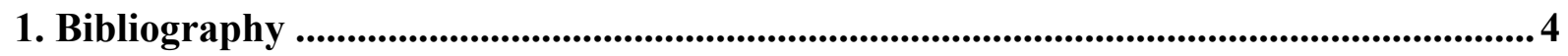

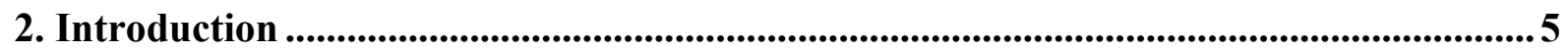

2.1 Adipokines - a link between body mass dyregulation and metabolic disturbances .....................5

2.2 Fibroblast growth factor-21 - a novel adipokine with beneficial properties ................................

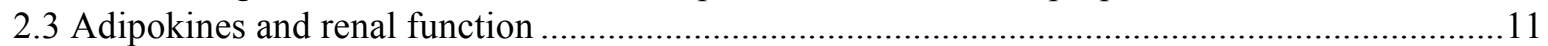

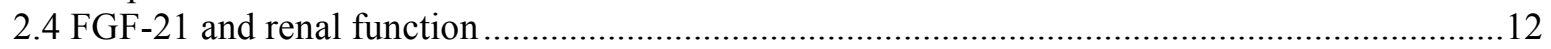

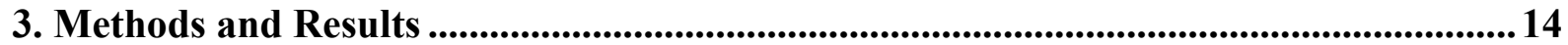

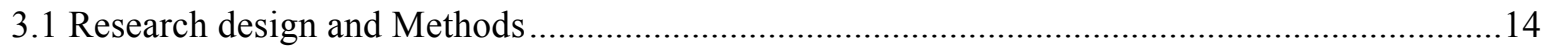

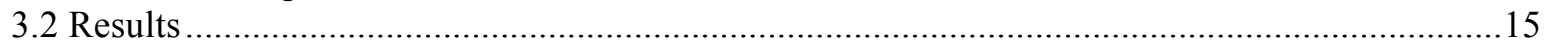

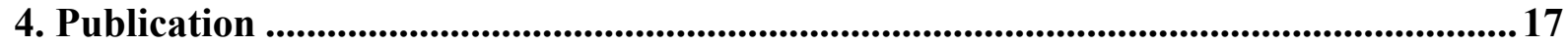

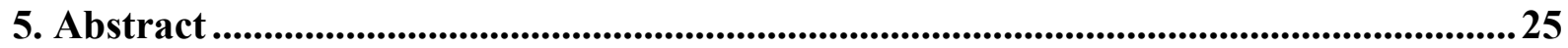

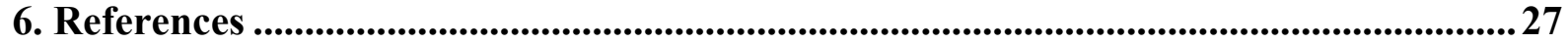

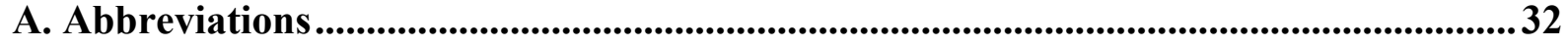

B. Erklärung über die eigenständige Abfassung der Arbeit ................................................333

C. Erklärung über die Vorbehaltlichkeit der Verfahrenseröffnung zur Verleihung des Titels Dr. med. ........................................................................................................................................34

D. Wissenschaftlicher Lebenslauf.

E. Danksagung 


\section{Bibliography}

Janka Hindricks

Serum levels of fibroblast growth factor-21 are increased in chronic and acute renal

dysfunction

Universität Leipzig, Dissertation

37 pages, 87 citations, 3 figures, 1 table, 5 appendices

The progressively increasing prevalence of the Metabolic Syndrome (MetS) has emerged as a major global health concern since the MetS is associated with an increased risk for cardiovascular morbidity and mortality. Central obesity represents a key feature of the MetS and is strongly related to all MetS comorbidities. Dysregulation of adipose tissue-derived proteins, so called adipokines, has been implied to partially contribute to these effects. Recently, fibroblast growth factor-21 (FGF-21) has been introduced as a novel insulin-sensitizing and weight-reducing adipokine with potential therapeutic properties.

However, data on FGF-21 elimination are rather limited. Therefore, FGF-21 regulation in relation to renal function has been investigated in a patient population with chronic kidney disease (CKD, study population 1), as well as one with acute kidney impairment (study population 2).

In study population $1(\mathrm{n}=499)$, patients were distributed into five CKD subgroups according to estimated glomerular filtration rate (eGFR). Median FGF-21 serum concentrations progressively increased from CKD stage 1 to stage 5 and highest values of FGF-21 were detected in stage 5 (1: $86.4 \mathrm{ng} / \mathrm{l} ; 2: 206.4 \mathrm{ng} / \mathrm{l} ; 3: 289.8 \mathrm{ng} / \mathrm{l} ; 4: 591.3 \mathrm{ng} / \mathrm{l} ; 5: 1918.1 \mathrm{ng} / \mathrm{l})$. Furthermore, eGFR remained the strongest predictor for FGF-21 levels in multivariate analysis. For study population $2(\mathrm{n}=32)$, blood samples were obtained before elective unilateral partial or total nephrectomy, as well as within 30 hours after surgery. In this population FGF-21 levels significantly increased after surgery (325.0 ng/l) as compared to before surgery (255.5 ng/l). Furthermore, relative changes of FGF-21 were independently and positively predicted by relative changes of creatinine in this cohort.

These results are in accordance with the hypothesis that FGF-21 is eliminated by the kidneys and that the extent of kidney dysfunction substantially contributes to serum FGF-21 levels. However, additional animal experiments and prospective clinical studies are needed to further elucidate the role of the kidneys in FGF-21 physiology. 


\section{Introduction}

\subsection{Adipokines - a link between body mass dyregulation and metabolic disturbances}

In the last decades, dramatic increases in the prevalence of the Metabolic Syndrome (MetS) have become a major global health concern. Thus, in the United States of America its prevalence increased from $23.1 \%$ to $26.7 \%$ within 12 years. ${ }^{1}$ Likewise, the prevalence of the MetS is beyond $20 \%$ in Germany. ${ }^{2}$

The MetS, also known as syndrome $\mathrm{X}^{3}$ and deathly quartet ${ }^{4}$ was primarily described in the late 1920 s as a combination of hyperglycemia, hypertension, and gout in patients with a predisposition for metabolic disease states. ${ }^{5}$ In 1947 , visceral adiposity has been integrated as an additional feature of this new syndrome. ${ }^{6}$ In 2001, the National Cholesterol Education Program (NCEP) has established a clinical definition for the MetS (Table 1) suitable for clinical practice and widely used today. ${ }^{7}$ In accordance with other well accepted definitions (World Health Organization, ${ }^{8}$ International Diabetes Federation ${ }^{9}$ ), the NCEP defines insulin resistance and central obesity as key aspects of the MetS.

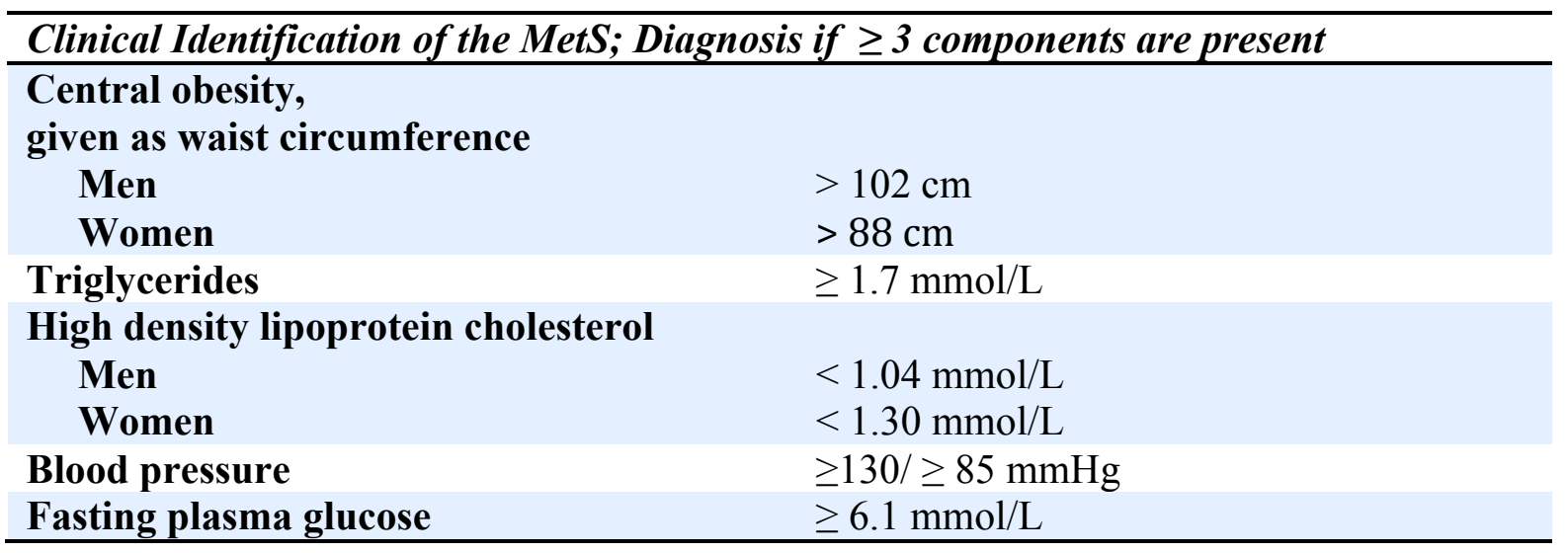

Table 1. Clinical criteria for the diagnosis of the MetS adapted from the executive Summary of the Third Report of the NCEP Expert Panel on Detection, Evaluation, and Treatment of High Blood Cholesterol in Adults ${ }^{\top}$

Onset of the MetS is associated with an increased risk for cardiovascular disease (CVD) including myocardial infarction and stroke $\mathrm{e}^{10,11}$ and subsequently an increase in cardiovascular mortality. $^{12}$

Out of all components, central obesity is most strongly associated with the MetS ${ }^{13}$ and weight loss therapy remains the primary treatment for the $\mathrm{MetS}^{7}$ as it improves all MetS aspects as well as cardiovascular outcomes. ${ }^{14,15}$ Central obesity is defined as indicated in Table $1^{16}$ and waist circumference is a reliable clinical predictor for the amount of visceral adipose tissue. ${ }^{17}$ 
Adipose tissue mass mainly consists of adipocytes but also pre-adipocytes, endothelial cells, and immune cells, as well as intercellular matrix. ${ }^{18}$ In general, adipose tissue has significant impact on energy and glucose homeostasis. Thus, the presence of insulin leads to enhanced glucose uptake whereas lipolytic hormones stimulate the release of fatty acids in starvation periods.

Notably, adipose tissue has also been identified as an important endocrine regulator in the last decades, providing a potential link between adipose tissue mass dysregulation and the occurrence of the MetS. In this context, adipocytokines or adipokines are adipose tissuesecreted proteins with numerous functions in human metabolic processes. Thus, adipokines are involved in glucose homeostasis, ${ }^{19}$ insulin secretion, ${ }^{20}$ and the regulation of food intake. ${ }^{21}$ Furthermore, dysregulation of adipokines is present in diseases affecting these processes e.g. type 2 diabetes mellitus (T2DM), insulin resistance, and obesity. ${ }^{22}$ Important adipokines relevant to the present study will be introduced in more details within the next paragraphs.

The beginning of a new understanding of adipose tissue function has been marked by the discovery of the adipokine leptin. As early as 1950, Ingalls and co-workers introduced a then unknown gene mutation in mice which is associated with a morbidly obese phenotype: the $o b$ gene. ${ }^{23}$ Weight gain in these mice is associated with massive overeating and leads to three times the body weight of healthy animals. In 1994 Zhang and co-workers reported the detection of a $16 \mathrm{kDa}$ protein encoded by the $o b$ gene and expressed almost exclusively in adipose tissue. ${ }^{24}$ The protein received the name leptin after the Greek word leptos, meaning thin. The leptin receptor has subsequently been detected in the choroid plexus of rodents ${ }^{25}$ and in high concentrations in the hypothalamus ${ }^{26}$ but it is also present in different tissues throughout the body. ${ }^{27-29}$ Soluble leptin binds to its receptor in the hypothalamic region and leads to a reduction of neuropeptide Y (NPY) mRNA expression ${ }^{26}$ a protein responsible for appetite and regulation of food intake. ${ }^{30}$ In health, leptin release from adipocytes is controlled by a negative feedback loop (Figure 1). 


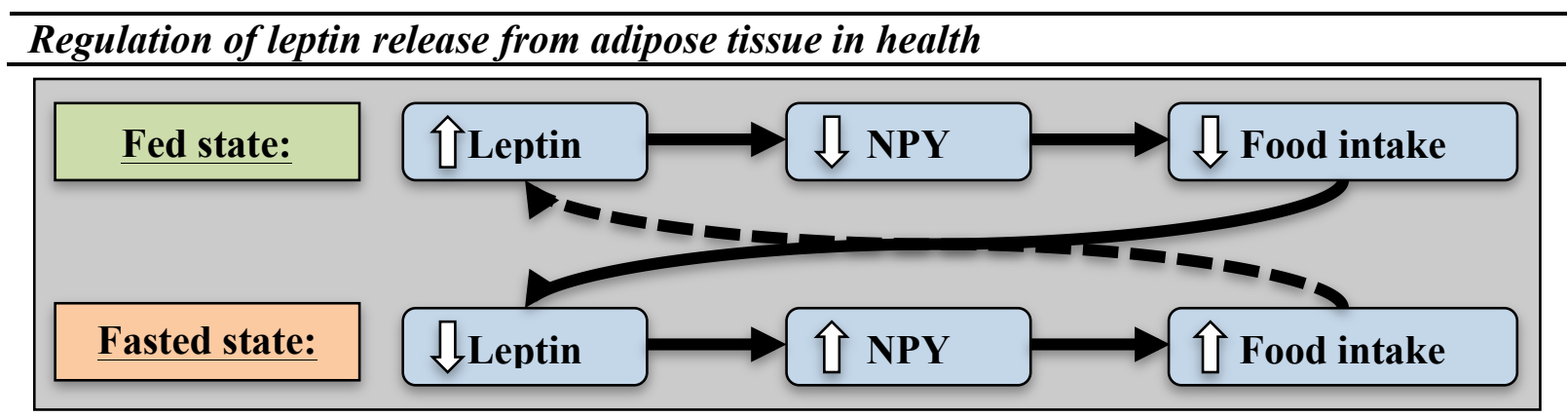

Figure 1. Simplified depiction of feedback processes for leptin release from adipocytes: In the fed state, increased leptin secretion leads to reduced NPY release. Subsequently, less food is consumed. In the fasted state decreased leptin concentrations lead to enhanced NPY release with increased food consumption.

These feedback mechanisms are extensively responsible for the balance between energy intake and energy expenditure. Hence, mutations of the $o b$ gene result in weight gain and metabolic disturbances e.g, hyperglycemia and hyperinsulinemia in rodents. ${ }^{24}$ Leptin administration leads to decreases in body weight and ameliorates glucose imbalance in leptin-deficient $o b / o b$, mice. ${ }^{31}$ Paradoxically, $o b / o b$ mice display limited progression of atherosclerosis ${ }^{32}$, whereas leptin administration results in worsening of atherosclerotic lesions. ${ }^{32}$ Apart from facets of the MetS, leptin is also involved in various processes including fertility $^{23}$ and bone metabolism. ${ }^{33}$

Along with the growing rates of obesity and T2DM, a lot of hope has been put into leptin as a therapeutic agent for facets of the MetS, especially due to the positive results of leptin administration on body weight of leptin-deficient rodents. ${ }^{34}$ In patients with lipodystrophy, a disorder characterized by leptin-deficiency, 4 months of subcutaneous leptin treatment in fact leads to improved lipid profile and reduced need of antidiabetic therapy. ${ }^{35}$ However, obese patients exhibit increased leptin gene expression in adipose tissue as compared to non-obese patients and levels of the adipokine highly correlate with body mass index. ${ }^{36}$ Furthermore, leptin levels predict worsening of the MetS independent from obesity. ${ }^{37}$ It is, therefore, postulated that obesity and other metabolic disturbances induce a leptin-resistant state comparable to insulin resistance in T2DM. Nonetheless, the pathophysiology behind the onset of leptin resistance remains unclear so far.

Another important adipokine closely linked to the MetS is adiponectin. Two years after the discovery of leptin, Maeda and co-workers demonstrated another gene almost exclusively and abundantly expressed in adipose tissue: the apM1 gene. ${ }^{38}$ Gene product is a 224 amino-acid, protein with similarities to collagen and complement 1q: adiponectin (apM1, AdipoQ). ${ }^{38}$ The 
adipokine binds to two receptors, AdipoR1 and AdipoR2 with different expression patterns in mice and humans. AdipR1 is found ubiquitously whereas AdipqR2 is predominantly expressed in the liver. ${ }^{39}$ Binding of the adipokine to its receptor leads to enhancements in fatty acid oxidation in skeletal muscle and liver cells, as well as stimulation of glucose uptake in skeletal muscle cells. ${ }^{39}$ Therefore, adiponectin is considered to be an adipokine with beneficial effects on glucose and lipid metabolism. In mouse 3T3-L1 preadipocytes, adiponectin mRNA expression increases considerably during differentiation and adiponectin stimulates adipocyte cell proliferation. ${ }^{40}$ Transgenic mice with adiponectin overexpression exhibit increased energy expenditure, a beneficial lipid profile, low blood glucose levels, and considerable decreases in adipocyte differentiation. ${ }^{41}$ In obese mice, levels of adiponectin are extensively decreased as compared to lean controls. ${ }^{42}$ Apart from obesity, plasma adiponectin levels are significantly reduced in various metabolic disturbances in rodents and primates. Adiponectin knockout mice display diet-induced insulin resistance ${ }^{43}$ and serum levels of the adipokine correlate inversely with the degree of insulin resistance in monkeys. ${ }^{44}$ In concordance with these results in animals, adiponectin concentrations are considerably decreased in humans with facets of the MetS as compared to normal-weight subjects. ${ }^{42}$ Furthermore, plasma adiponectin levels are reduced in diabetic patients as compared to healthy controls. ${ }^{45}$ Moreover, adiponectin concentrations are an independent predictor for the occurrence of the $\mathrm{MetS}^{46}$ and are negatively associated with blood pressure in 21,000 healthy subjects. $^{47}$

Since CVD represents the leading cause for MetS-associated morbidity and mortality, the role of adiponectin in CVD has been subject to through investigations by different groups. Interestingly, adiponectin has anti-atherogenic effects. ${ }^{48}$ Mechanisms for these beneficial effects of adiponectin include anti-inflammatory properties and decreased tumor necrosis factor (TNF) $\alpha$-induced monocyte adhesion. ${ }^{48}$ Since patients with CVD generally exhibit low levels of adiponectin ${ }^{48}$, hypoadiponectaemia in the MetS might contribute to increased risk for cardiovascular events.

Apart from adiponectin, chemerin represents an additional adipokine with metabolic, as well as chemotactic, properties. Chemerin was primarily discovered in the 1990's as a product of the tazarotene-induced gene 1 or retinoid acid receptor responder 2, a gene responsive to retinoid acid treatment in psoriasis, an inflammatory skin disease. ${ }^{49}$ The adipokine is ligand to three different receptors: chemokine receptor-like 1 (CMKLR1), chemokine receptor-like 2 (CCRL2), and G protein-coupled receptor 1 (GPCR1) with different expression patterns 
throughout the body. CMKLR1 is predominantly expressed in white adipose tissue of mice, whereas high concentrations of CCRL2 and GPCR1 are found in rodent skeletal muscle cells. ${ }^{50}$ While CCRL2 and GPCR1 function remains to be elucidated, binding of chemerin to the CMKLR1 stimulates migration of macrophages and immature dendritic cells to sites of injury in vitro ${ }^{51}$ Furthermore, similar to adiponectin, chemerin is induced during adipocyte differentiation in vitro. ${ }^{52}$ Moreover, incubation of 3T3-L1 preadipocytes with chemerin significantly increases insulin-stimulated glucose uptake. ${ }^{53}$ Extensive studies in leptindeficient $o b / o b$ and leptin receptor-deficient $d b / d b$ mice, which serve as models for obesity and T2DM, demonstrate significant increases in total chemerin concentration and decreases in CMKLR1 expression in white adipose tissue as compared to healthy mice. ${ }^{50}$ Furthermore in contrast to in vitro studies, chemerin administration results in aggravation of glucose intolerance by decreasing glucose uptake and insulin secretion in obese, as well as diabetic, mice. $^{50}$

Chemerin concentrations correlate positively with markers of inflammation, e.g. C- reactive protein (CRP), interleukin-6 (IL-6). and TNF- $\alpha$ in human subjects. ${ }^{54}$ Circulating chemerin is significantly and positively associated with multiple facets of the MetS. ${ }^{54}$ However, chemerin regulation in insulin resistance, as well as CVD, in humans remains controversial. Thus, Spiroglou and co-workers reveal a positive association between chemerin levels and coronary atherosclerosis whereas no association is seen in another study. ${ }^{54,55}$ Furthermore upregulation and no regulation of the adipokine in T2DM have been reported. ${ }^{56,57}$

\subsection{Fibroblast growth factor-21 - a novel adipokine with beneficial properties}

The fibroblast growth factor (FGF) family is a group of proteins with various effects on human and animal cells including, angiogenesis, embryogenesis and regulation of cell survival. ${ }^{58}$ With first recognition in $1974^{59}$, to date the FGF family consists of 22 members, which can be further subcategorized into three groups: intracellular, paracrine, and hormonelike subfamily. ${ }^{60}$ Extensive research during the last decades is only beginning to elucidate the role of the hormone-like subfamily members, e.g. FGF-15, FGF-21 and FGF-23, in human metabolic processes.

FGF-21 is a 181 amino acid protein which binds to the FGF receptor, a transmembrane tyrosine kinase, in a $\beta$-Klotho dependent manner. ${ }^{60}$ FGF-21 was initially identified in liver and thymus tissue of mouse embryos by Nishimura and co-workers in $2000{ }^{61}$ Soon after, adipose tissue has been revealed as an additional source of FGF-21 expression. ${ }^{62}$ Research on FGF-21 action in adipose tissue demonstrates progressive increases in FGF-21 mRNA 
expression during adipogenesis. ${ }^{62}$ Furthermore, FGF-21 mediates insulin-independent stimulation of glucose uptake in differentiated adipocytes. ${ }^{63}$ In more detail, binding of the adipokine to the FGF receptor induces an intracellular signal cascade leading to increased glucose transporter (GLUT)-1 gene expression. ${ }^{64}$ Subsequent translocation of GLUT-1 generates increased glucose uptake in adipocytes.

In animal models, FGF-21 mRNA expression increases in adipose tissue and liver of diet-induced obese mice and treatment with FGF-21 reduces body weight and ameliorates insulin resistance in these mice. ${ }^{65,66}$ Administration of FGF-21 to diabetic primates leads to improved serum glucose and lipid profiles. ${ }^{67}$

It is apparent that due to its beneficial effects on insulin resistance, central obesity, and serum lipids in rodents, FGF-21 functions as a potential pharmacological target for the treatment of these metabolic disturbances seen in the MetS. Therefore, over the past years, several studies have focused on FGF-21 regulation in human subjects with components of the MetS. In this context, data of FGF-21 serum levels in patients with T2DM, an insulin resistant state, reveal significant upregulation of the adipokine as compared to healthy controls. ${ }^{68,69}$ Furthermore, two independent studies show elevated FGF-21 levels in obese as compared to normal-weight subjects. ${ }^{62,70}$ Notably, FGF-21 independently predicts the occurrence of the MetS in a longitudinal study with 440 patients. ${ }^{71}$ Furthermore, Zhang and co-workers demonstrate a progressive increase in FGF-21 levels with increasing number of MetS components. ${ }^{62}$

The paradoxical increase of the beneficial adipokine FGF-21 in humans with facets of the MetS is subject of ongoing investigations. It appears that FGF-21 resistance in the MetS, similar to leptin resistance, is at least partially accountable for this upregulation.. Additionally and alternatively, FGF-21 induction might be a compensatory response to limit the adverse consequences of MetS components on metabolic and vascular health. 


\subsection{Adipokines and renal function}

The kidneys are substantially involved in the regulation of various processes in humans. Apart from adjusting blood pressure, as well as maintaining acid-base and fluid balance, filtration of blood followed by excretion of waste products is another important task.

According to the Kidney Disease: Improving Global Outcomes criteria, chronic kidney disease (CKD) is defined as abnormalities of kidney structure or function, present for more than three months, alongside implications for health. The deterioration of renal function substantially contributes to an increased risk for CVD and premature death. ${ }^{72}$ Several features of patients with MetS, such as T2DM and hypertension ${ }^{73}$ have long been held accountable for these adverse outcomes in patients with CKD. However, recent studies suggest additional pathophysiological mechanisms responsible for the increase in cardiovascular events in patients with impaired renal function. It has been demonstrated, that diminished elimination of adipokines in patients with kidney function impairment significantly adds to the occurrence of CVD. ${ }^{74}$ Therefore, adipokine regulation in relation to renal function has been subject to profound investigations over the last years.

In this context, Cumin and co-workers have been among the first groups to provide substantial evidence that leptin is eliminated by the kidneys by performing bilateral nephrectomy as compared to sham operation in rats. In more detail, levels of the adipokine spike significantly and immediately after the surgery and progressively increase within the next $48 \mathrm{~h}$. Gel electrophoresis further shows that leptin levels are decreased in venous as compared to arterial renal blood and extraction rate is calculated at $45 \%$. However, only small amounts of leptin are found in urine suggesting renal metabolization rather than excretion. ${ }^{75}$ In humans, Sharma and co-workers have quantified leptin levels in human aortic and renal vein blood. Leptin concentrations are decreased by $12 \%$ in renal vein as compared to aortic blood in healthy patients whereas leptin levels remain constant in patients with mild to moderate stages of CKD. Moreover, serum levels of the adipokine are 4.5 fold increased in a second cohort with end-stage renal disease (ESRD). ${ }^{76}$ Notably, leptin serum concentrations significantly and negatively correlate with glomerular filtration rate. ${ }^{77}$ Since leptin is considerably contributing to worsening of atherosclerosis ${ }^{32}$, it has been suggested that hyperleptinaemia seen in patients with deteriorating renal function should be subject to therapeutic intervention. ${ }^{78}$ In contrast, adiponectin is associated with a beneficial metabolic and cardiovascular profile. ${ }^{48}$ Animal studies of renal function-associated adiponectin regulation have revealed hyperadiponectinaemia in male mice one month after subtotal 
nephrectomy. Furthermore, injection of wild type plasma to adiponectin knockout mice reveals lower adiponectin clearance rates in nephrectomized as compared to sham-operated mice, again indicating renal elimination of the adipokine. ${ }^{79}$ In humans, deterioration of renal function results in progressive elevation of serum adiponectin levels and patients with ESRD receiving kidney transplants exhibit lower levels of adiponectin after as compared to before transplantation. ${ }^{80}$ Since a beneficial role of the adipokine in CVD is implied, several studies focus on hyperadiponectaemia in renal disease in relation to cardiovascular events. However, data remain controversial. Thus, Becker and co-workers demonstrate low adiponectin levels as a risk factor for cardiovascular events in a prospective study of patients with renal dysfunction. ${ }^{81}$ In contrast, a decreased risk for cardiovascular mortality is shown in patients with low adiponectin concentrations in another study. ${ }^{82}$ In accordance with studies on leptin and adiponectin, chemerin serum concentrations are also upregulated in humans with impaired renal function. Recently, our group has demonstrated significant upregulation of the adipokine in patients undergoing chronic hemodialysis as compared to healthy controls. ${ }^{83}$ In this study, estimated glomerular filtration rate (eGFR) remains an independent predictor for circulating chemerin in ESRD patients. ${ }^{83}$ In accordance with our findings, Yamamoto and coworkers also reveal a negative correlation between chemerin and eGFR in a study population of 252 patient with CKD stage $5 .{ }^{84}$ Notably in a 5-year follow-up, high chemerin levels at baseline have predicted a better overall survival. ${ }^{84}$ In addition, ESRD patients exhibit $30 \%$ higher chemerin serum levels before as compared to after receiving kidney transplant. ${ }^{85}$

\subsection{FGF-21 and renal function}

In contrast to these well-described adipokines, i.e. leptin, adiponectin, and chemerin, data on FGF-21 regulation in relation to renal function are particularly limited. Thus, our group has been the first to describe an association between the adipokine and renal function in a small study population of patients undergoing chronic hemodialysis $(n=120) .{ }^{86}$ Data on these patients with extensively diminished renal function revealed significant increases in FGF-21 levels in comparison with healthy controls. Furthermore, eGFR negatively predicts levels of the adipokine. ${ }^{86}$ In agreement with these findings, Lin and co-workers demonstrate increased FGF-21 serum concentrations in a small patient population with severe as compared to mild CKD ${ }^{87}$ However, patient numbers in these studies have been rather small and none of the studies covered all stages of CKD. Furthermore, to the best of our knowledge, no data are available on FGF-21 regulation in patients with acute kidney injury. To address these limitations, FGF-21 serum concentrations were quantified in a large cohort of 499 patients 
covering CKD stages 1 to 5. Furthermore, we measured FGF-21 levels in 32 patients undergoing elective partial or total unilateral nephrectomy. Moreover, in both study populations, FGF-21 levels were correlated with biochemical and anthropometric measures of renal function, inflammation, glucose metabolism, and lipid metabolism. We hypothesized that:

1. FGF-21 levels progressively increase with increasing CKD stage in humans.

2. FGF-21 serum concentrations increase in patients with acute kidney injury. 


\section{Methods and Results}

\subsection{Research design and Methods}

To address the hypotheses summarized in 2.4. two different study populations were recruited. Study population 1 consisted of 499 patients (men: $n=280$; women: $n=219$ ) with varying degrees of CKD $(1: \mathrm{n}=48 ; 2: \mathrm{n}=88 ; 3: \mathrm{n}=128 ; 4: \mathrm{n}=54 ; 5: \mathrm{n}=181)$. Stages of CKD were defined according to the Kidney Disease Outcomes Quality Initiative (KDOQI) guidelines. Thorough clinical examination and questionnaire on past medical history were conducted prior to the collection of blood samples under fasting conditions ( $>8$ hours after last meal). In patients on hemodialysis, blood samples were taken before hemodialysis started.

Study population 2 included 32 patients (men: $n=26$; women: $n=6$ ) from the Department of Urology, University of Leipzig, undergoing partial or total unilateral nephrectomy. Again, patients received a thorough clinical examination and a questionnaire on past medical history was completed. Blood samples under fasting conditions were taken prior to surgery, as well as within 30 hours after surgery.

In both study populations, biochemical parameters were measured by the Institut für Labormedizin, Klinische Chemie und Molekulare Diagnostik, Leipzig. Levels of adiponectin, leptin, and FGF-21 were quantified by commercial enzyme-linked immunoabsorbant assays. Written informed consent was obtained from all patients. Statistical analyses were conducted using SPSS software version 20.0. 


\subsection{Results}

In study population 1, median FGF-21 serum levels progressively increased from CKD stage 1 to CKD stage 5 (1: $86.4 \mathrm{ng} / \mathrm{l} ; 2: 206.4 \mathrm{ng} / 1 ; 3: 289.8 \mathrm{ng} / \mathrm{l} ; 4: 591.3 \mathrm{ng} / \mathrm{l} ; 5: 1918.1 \mathrm{ng} / \mathrm{l})$. Significant increases are depicted in Figure 2.

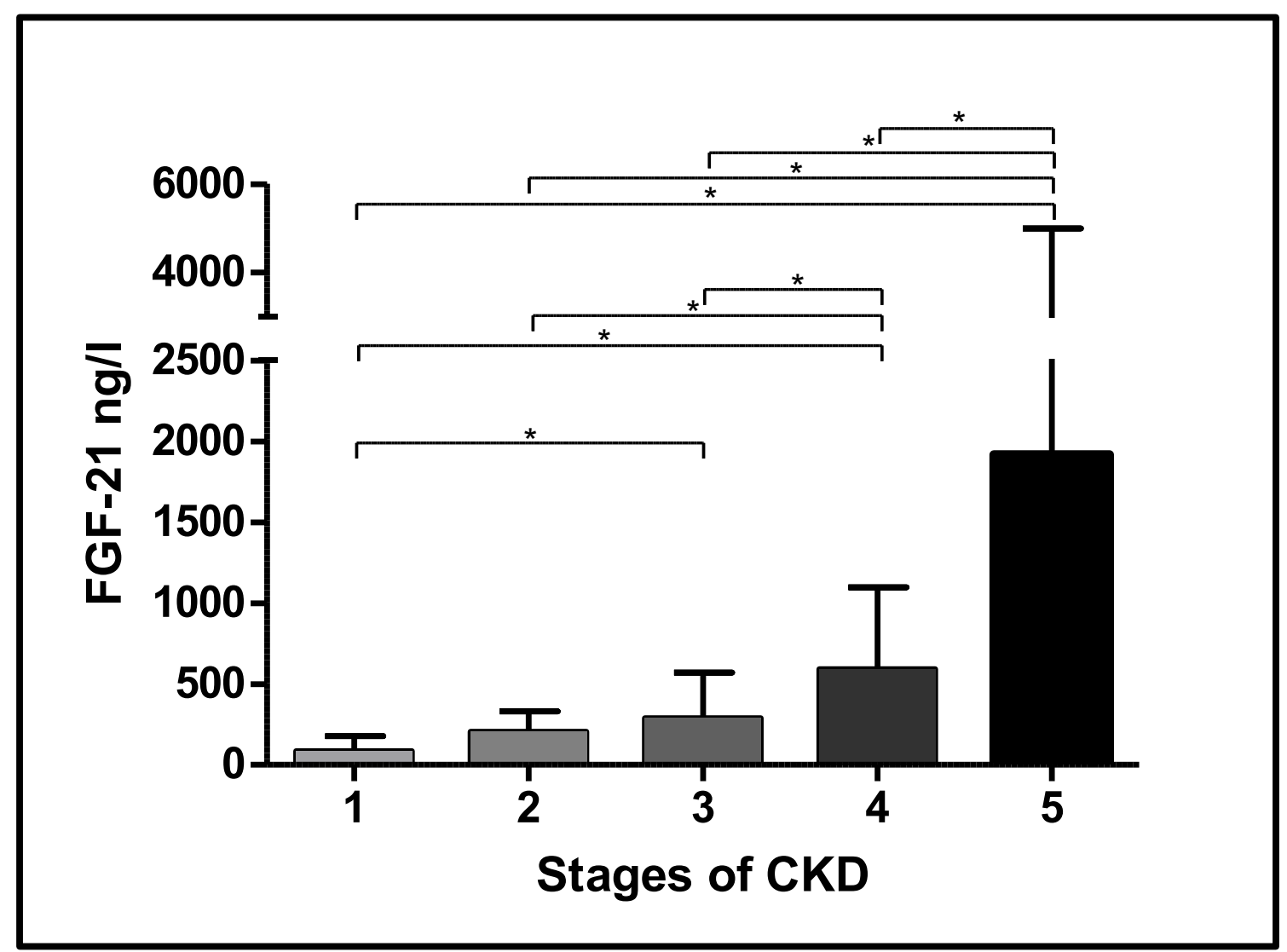

Figure 2. Median values (interquartile range) of FGF-21 serum concentrations in relation to CKD stage according to the KDOQI guidelines $(n=499)$. * indicates statistical significance $(p<0.05)$.

Furthermore, patients with diabetes mellitus exhibited significantly higher values of FGF-21 $(619.7 \mathrm{ng} / \mathrm{l})$ as compared to patients without diabetes $(437.1 \mathrm{ng} / \mathrm{l})(\mathrm{p}=0.003)$. Moreover, men $(552.1 \mathrm{ng} / \mathrm{l})$ had significantly higher levels of FGF-21 as compared to women (441.2 ng/l) (p $=0.020)$. Univariate correlation method revealed significant and positive associations between FGF-21 on one hand and age, waist-to-hip ratio (WHR), waist-to-height ratio, serum creatinine, triglycerides, high sensitivity (hs)CRP, hsIL-6, leptin, and adiponectin on the other hand. Furthermore, a significant and negative correlation was present between FGF-21 levels and diastolic blood pressure, eGFR, fasting glucose, cholesterol, HDL cholesterol, and lowdensity lipoprotein (LDL) cholesterol. In multivariate regression analysis, the renal marker eGFR remained the strongest negative predictor for FGF-21 levels. Furthermore, a negative 
association was observed with LDL cholesterol whereas a positive association between FGF-21 levels on the one hand and WHR, triglycerides, and adiponectin on the other hand persisted in multiple regression analysis.

In study population 2, Median FGF-21 levels significantly increased in patients after unilateral partial or total nephrectomy $(325.0 \mathrm{ng} / \mathrm{l})$ as compared to before surgery $(255.5 \mathrm{ng} / \mathrm{l})$ $(\mathrm{p}<0.05)$ (Figure 3).

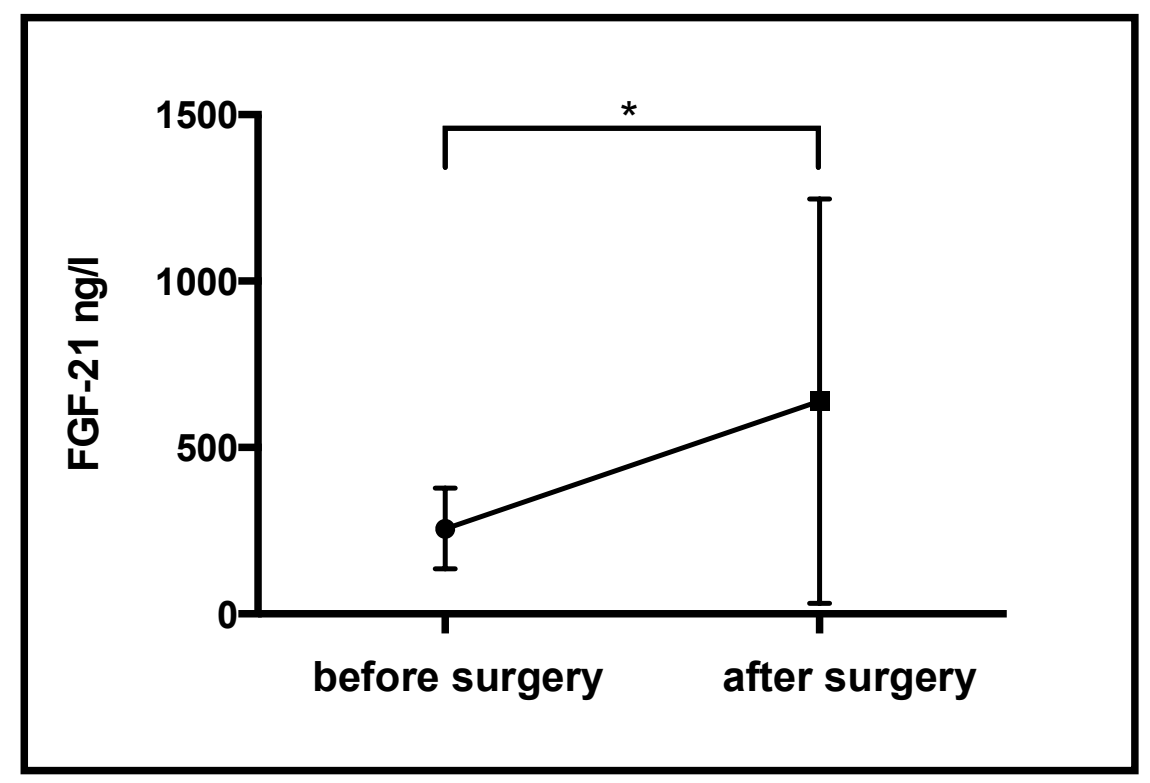

Figure 3. Median (interquartile range) FGF-21 serum concentrations in patients before and after unilateral partial or total nephrectomy $(n=32)$ * indicates statistical significance $(p<0.05)$ assessed after Wilcoxon signed-rank test.

Furthermore, creatinine, hsCRP and hsIL-6 significantly increased whereas eGFR, levels of triglycerides, cholesterol, HDL and LDL cholesterol and adiponectin significantly decreased after surgery. Moreover, relative changes (post-to-presurgery) of FGF-21 serum concentrations correlated negatively with relative changes of eGFR and positively with relative changes of creatinine in univariate analysis. In addition, relative changes of creatinine remained a strong predictor for relative changes of FGF-21 levels in multivariate analysis even after adjustment for age and gender $(\mathrm{p}<0.001)$.

These results support the hypothesis that FGF-21 levels in humans are closely linked to renal function, assessed as eGFR, in patients with CKD, as well as acute renal dysfunction.

Furthermore, eGFR is an independent predictor for FGF-21 serum concentrations in these two patient populations. 


\section{Publication}

Title:

Authors:

Submission:

Accepted:

Published:
Serum levels of fibroblast growth factor-21 are increased in chronic and acute renal dysfunction

J Hindricks, T Ebert, A Bachmann, S Kralisch, U Lössner, J Kratzsch, J-U Stolzenburg, A Dietel, J Beige, M Anders, I Bast, M Blüher, M Stumvoll, M Fasshauer

August $16^{\text {th }} 2013$

December $2^{\text {nd }} 2013$

Clinical Endocrinology

Volume 80

Issue 6

Pages 918-924

June 2014 


\title{
ORIGINAL ARTICLE
}

\section{Serum levels of fibroblast growth factor-21 are increased in chronic and acute renal dysfunction}

\author{
Janka Hindricks*'†, ${ }^{*}$, Thomas Ebert*'†' ${ }^{*}$, Anette Bachmann*, Susan Kralisch*'†, Ulrike Lössner*'†, \\ Jürgen Kratzsch‡, Jens-Uwe Stolzenburg§, Anja Dietel§, Joachim Beigeף, Matthias Anders**, Ingolf Bast**, \\ Matthias Blüher*, Michael Stumvoll* and Mathias Fasshauer* $\dagger$
}

${ }^{*}$ Department of Endocrinology and Nephrology, University of Leipzig, $\dagger$ IFB Adiposity Diseases, Leipzig University Medical Center $\$$ Institute of Laboratory Medicine, University of Leipzig, §Department of Urology, University of Leipzig, IDivision of Nephrology and KfH Renal Unit, Hospital St. Georg and ${ }^{* *}$ Outpatient Nephrology Care Units, Leipzig, Germany

\begin{abstract}
Summary
Objective Fibroblast growth factor (FGF)-21 has recently been introduced as a circulating adipokine which reverses insulin resistance and obesity in rodents. In this study, regulation of FGF-21 in renal dysfunction was elucidated in both chronic kidney disease (CKD) and acute kidney dysfunction (AKD).

Study design and methods Serum concentrations of total FGF-21 were quantified by enzyme-linked immunosorbent assay in 499 patients with CKD stages 1-5 (study population 1). Furthermore, total FGF-21 was determined before and within $30 \mathrm{~h}$ after unilateral nephrectomy, a model of AKD, in 32 patients (study population 2). FGF-21 levels were correlated to anthropometric and biochemical parameters of renal function, glucose and lipid metabolism, as well as inflammation, in both studies.

Results In study population 1, median [interquartile range] circulating FGF-21 adjusted for age, gender and body mass index was significantly different between CKD stages with highest values detectable in stage 5 (stage 1: 86.4 [132.9]; 2: 206.4 [223.1]; 3: $289 \cdot 8$ [409.3]; 4: 591.3 [789.0]; 5: 1918.1 [4157.0] ng/l). Furthermore, estimated glomerular filtration rate remained a strong independent and negative predictor of FGF-21. In study population 2, FGF-21 increased significantly postsurgically $(325 \cdot 0[984 \cdot 0] \mathrm{ng} / \mathrm{l})$ as compared to presurgical values $(255.5[243.0] \mathrm{ng} / \mathrm{l})$. Furthermore, relative changes of FGF-21 were independently and positively predicted by relative changes of creatinine.

Conclusions We demonstrate that circulating FGF-21 is increased in both CKD and AKD. Our results suggest renal excretion as a major route for FGF-21 elimination. The pathophysiological significance of these findings needs to be elucidated in more detail.
\end{abstract}

Correspondence: Thomas Ebert, Department of Endocrinology and Nephrology, University of Leipzig, Liebigstr. 20, 04103 Leipzig, Germany. Tel.: 49341 9713380; Fax: 49341 9713389; E-mail: thomas.ebert@ medizin.uni-leipzig.de

${ }^{1}$ These authors equally contributed to this work.
(Received 16 August 2013; returned for revision 11 September 2013; finally revised 2 December 2013; accepted 2 December 2013)

\section{Introduction}

Various adipocyte-secreted factors, so-called adipokines, contribute to facets of the metabolic syndrome (MetS). Thus, the adipokine adiponectin induces a beneficial metabolic profile. ${ }^{1}$ In contrast, the appetite-suppressive adipokine leptin is upregulated in obesity ${ }^{1}$ and associated with an increased risk of cardiovascular disease (CVD). ${ }^{1}$ Furthermore, the adipokine interleukin-6 induces insulin resistance and is associated with risk factors for CVD in humans.

Recently, fibroblast growth factor (FGF)-21, a member of the FGF family, has been introduced as an adipokine stimulating glucose uptake in adipocytes ${ }^{2}$ and increasing insulin sensitivity in rodents. ${ }^{3}$ However, the adipokine is paradoxically upregulated in various metabolic disease states in human subjects. ${ }^{4,5}$ Thus, Lin et al. ${ }^{4}$ have revealed upregulation of FGF-21 in 135 patients with coronary heart disease as compared to healthy controls. Moreover, Chavez et al..$^{5}$ demonstrated increased FGF-21 serum levels in patients with type 2 diabetes mellitus as compared to healthy controls. Taking these studies into account, FGF-21 appears to be an adipokine with multiple beneficial metabolic effects in rodents. However, exact mechanisms of FGF-21 upregulation in human metabolic disease remain unclear.

In contrast to these extensive studies in human metabolic disease, elimination of FGF-21 has not been studied in detail so far. Most importantly, previous studies on FGF-21 and renal function $^{6-8}$ show the following limitations: none of the studies (i) included $>250$ patients; (ii) covered the whole spectrum of renal dysfunction ranging from CKD stages 1-5 comprehensively; and (iii) elucidated the role of acute decreases in kidney function on FGF-21 serum levels. To address these issues and to more definitely define the role of the kidney in FGF-21 elimination, we quantified FGF-21 serum concentrations in 499 patients covering the whole spectrum of CKD (study population 1). 
Furthermore, we evaluated for the first time FGF-21 serum levels in 32 patients before and after unilateral partial or total nephrectomy (study population 2). Moreover, we correlated the adipokine to clinical and biochemical parameters of renal function, glucose and lipid metabolism, as well as inflammation.

We hypothesized that FGF-21 serum concentrations (i) increase with deteriorating renal function in CKD (study population 1) and (ii) are increased in acute renal dysfunction after nephrectomy (study population 2).

\section{Research design and methods}

\section{Subjects}

Study population 1. For this cross-sectional study, 532 patients (men: $n=305$; women: $n=227$ ) were recruited between 2006 and 2010 by the Department of Endocrinology and Nephrology, University of Leipzig and from three outpatient Nephrology Care Units (Hospital St. Georg, Division of Nephrology, KfH Renal Unit, 04129 Leipzig; outpatient Nephrology Care Units, 04107 and 04178 Leipzig) as described in detail recently. ${ }^{9}$ Prior to analyses, all patients on peroxisome proliferator-activated receptor (PPAR) $\alpha$ - and PPAR $\gamma$-agonists were excluded, and 499 patients remained in the study. Study participants underwent a thorough examination including anthropometric measures of obesity (waist and hip circumference, height, body mass index [BMI], waist-to-hip ratio [WHR] and waist-to-height ratio $[\mathrm{WHtR}])$, hypertension and a standardized questionnaire on past medical history. Furthermore, blood samples were drawn after an overnight fast at the respective care units. In haemodialysis patients, blood samples were taken right before haemodialysis started. Age of the study population was between 19 and 92 years, and BMI ranged from 14.3 to $49 \cdot 0 \mathrm{~kg} / \mathrm{m}^{2}$. Estimated glomerular filtration rate (eGFR) was calculated according to the Modification of Diet in Renal Disease (MDRD) formula ${ }^{10}$, and all patients were classified into chronic kidney disease (CKD) stages 1-5 according to the National Kidney Foundation - Kidney Disease Outcomes Quality Initiative (KDOQI) guidelines. ${ }^{11}$ Homeostasis model assessment of insulin resistance (HOMA-IR) was determined as described. ${ }^{12}$

Study population 2. For this longitudinal cohort, 32 patients (men: $n=26$; women: $n=6$ ) undergoing elective partial or total unilateral nephrectomy were recruited by the Department of Urology and the Department of Endocrinology and Nephrology, University of Leipzig. Recent studies convincingly demonstrated that these patients serve as a model for acute kidney dysfunction (AKD). ${ }^{13,14}$ The study design was described recently. ${ }^{15}$ Indications for surgery included renal carcinoma, renal shrinkage and renal cysts. The following inclusion and exclusion criteria were applied: inclusion criteria, age between 18 and 80 years; and exclusion criteria, haemodialysis, hereditary renal cysts, glomerulonephritis and generalized inflammation. Blood samples under fasting conditions were obtained shortly before renal surgery (median [interquartile range] time of the first blood sampling 08:15 [2:00] AM), as well as within $30 \mathrm{~h}$ after surgery (05:00 [0:22] AM). Age of the study population ranged from 22 to 78 years and BMI from $18 \cdot 2$ to $37 \cdot 0 \mathrm{~kg} / \mathrm{m}^{2}$. Anthropometric data (BMI, WHR and WHtR), as well as HOMA-IR, were assessed as described previously. For this population, eGFR was calculated using the Chronic Kidney Disease Epidemiology Collaboration formula including four parameters (serum creatinine, gender, race and age). ${ }^{16}$

Both studies were approved by the local Ethics Committee, and written informed consent was obtained from all patients before taking part in the studies.

\section{Assays}

Serum concentrations of total FGF-21 were determined with a commercial enzyme-linked immunosorbent assay (ELISA) from Biovendor (Modrice, Czech Republic). Intra- and interassay coefficients were $<4.1 \%$ and $3.9 \%$, respectively. Sensitivity was $7 \mathrm{ng} / \mathrm{l}$, and the ELISA was specific for human FGF-21 with no cross-reactivity with human FGF-19 and human FGF-23. Normal median FGF-21 levels for patients beyond 50 years of age were given by the manufacturer as follows: female $222.2 \mathrm{ng} / \mathrm{l}$ and male $237.4 \mathrm{ng} / \mathrm{l}$. Leptin was quantified with a high-sensitivity ELISA from Mediagnost (Reutlingen, Germany). Intra- and interassay coefficients were $<4.4 \%$ and $7.5 \%$, respectively. Sensitivity was $0 \cdot 2 \mu \mathrm{g} / \mathrm{l}$, and the ELISA was specific for human leptin with no cross-reactivity to other proteins such as insulin or insulin-like growth factor-1. Normal median leptin levels for subjects with a BMI of $25 \mathrm{~kg} / \mathrm{m}^{2}$ were given by the manufacturer as follows: female $11.9 \mu \mathrm{g} / \mathrm{l}$ and male $3.18 \mu \mathrm{g} / \mathrm{l}$. Total adiponectin was determined with an ELISA from Mediagnost (Reutlingen, Germany). Intra- and interassay coefficients were $<4.7 \%$ and $6.7 \%$, respectively. Sensitivity was $0.6 \mu \mathrm{g} / \mathrm{l}$, and the ELISA was specific for human adiponectin with no cross-reactivity to other species. Normal median adiponectin levels were given by the manufacturer as follows: female $9 \cdot 1 \mathrm{mg} / \mathrm{l}$ and male $6 \cdot 1 \mathrm{mg} / \mathrm{l}$. Total rather than other molecular isoforms of adiponectin, for example high molecular weight adiponectin, was quantified in this study as most analyses in the literature concerning adiponectin and metabolic disease have been performed with assays quantifying total protein. ${ }^{17,18}$ In all patients, serum concentrations of high-sensitivity interleukin-6 (hsIL-6) were determined with a commercial ELISA from R\&D Systems (Minneapolis, $\mathrm{MN}$, USA) according to the manufacturer's instructions. Intraand interassay coefficients were less than $4 \cdot 2 \%$ and $6 \cdot 4 \%$, respectively. Sensitivity was $0.7 \mathrm{ng} / \mathrm{l}$, and the ELISA was specific for human IL-6 with no cross-reactivity to other species and interleukins. Serum creatinine, fasting glucose (FG), fasting insulin (FI), triglycerides (TG), cholesterol, high-density lipoprotein (HDL) cholesterol, low-density lipoprotein (LDL) cholesterol and high-sensitivity C-reactive protein (hsCRP) were measured in a certified laboratory by standard methods.

\section{Statistical analysis}

spss software version 20.0 (IBM, Armonk, NY, USA) was used for all statistical analyses. 
920 J. Hindricks et al.

In study population 1 , overall group differences for continuous parameters were assessed by Kruskal-Wallis test followed by post-hoc analysis with prior adjustment for age, gender and BMI. Univariate correlations were assessed by nonparametric Spearman's rank correlation method. Furthermore, multivariate linear regression analysis was performed. Prior to the multivariate analysis, distribution of continuous variables was tested for normality using the Shapiro-Wilk-test, and non-normally distributed parameters were logarithmically transformed.

In study population 2, differences in FGF-21 serum concentrations and other laboratory parameters before and after renal surgery were assessed by Wilcoxon signed-rank test for related samples. Furthermore, relative changes (postsurgical-to-presurgical ratios) were calculated for all laboratory parameters as follows: parameter $($ ratio $)=$ parameter $_{\text {postsurgery }} /$ parameter presurgery similar to other studies. ${ }^{19}$ Univariate correlation analysis was performed by Spearman's rank correlation method using these relative changes (ratios). Afterwards, multivariate linear regression analysis was performed as described previously. In all multivariate linear analyses, parameters that correlated significantly with FGF-21 in univariate analysis were included. For covariates, for example creatinine and eGFR, the parameter with the strongest univariate correlation was included in the multivariate model. Furthermore, age and gender were included in all multivariate analyses. A $P$-value of $<0.05$ was considered as statistically significant in all analyses.

\section{Results}

\section{Study population 1}

FGF-21 serum concentrations are increased in patients with $C K D$. The clinical characteristics of the five CKD subgroups studied are summarized in Table 1. Median [interquartile range] FGF-21 levels were $512.7[1204 \cdot 1] \mathrm{ng} / \mathrm{l}$ in the total study population. FGF-21 levels were significantly different between the five CKD stages $(P<0.001)$. Serum FGF-21 concentrations increased with deteriorating renal function, and highest values were seen in CKD stage 5 (Table 1). When patients were divided according to diabetes mellitus status, circulating median [interquartile range] FGF-21 was significantly higher in patients with diabetes mellitus $(619.7[1696 \cdot 8] \mathrm{ng} / \mathrm{l})$ as compared to nondiabetic subjects $(437.1 \quad[1147 \cdot 3] \quad \mathrm{ng} / \mathrm{l}) \quad(P=0.003)$. In contrast, FGF-21 was not significantly different between overweight/obese patients $(476.6[1094.5] \mathrm{ng} / \mathrm{l})$ as compared to lean subjects $(555.2[1738 \cdot 0] \mathrm{ng} / \mathrm{l})(P=0.492)$. Moreover, FGF21 levels were significantly higher in men $(552 \cdot 1$ [1570.1] ng/l) as compared to women $(441 \cdot 2[797 \cdot 1] \mathrm{ng} / \mathrm{l})(P=0 \cdot 020)$. In

Table 1. Baseline characteristics of the study population 1, divided into five stages of CKD

\begin{tabular}{|c|c|c|c|c|c|}
\hline$N$ & 48 & 88 & 128 & 54 & 181 \\
\hline Age (years) & $55 \cdot 3(16 \cdot 3)$ & $64 \cdot 7(14 \cdot 7)$ & $72 \cdot 8(15 \cdot 2)^{1,2}$ & $76 \cdot 7(14 \cdot 1)^{1,2}$ & $66 \cdot 3(21 \cdot 1)^{1,3,4}$ \\
\hline Gender $(\mathrm{m} / \mathrm{f})$ & $25 / 23$ & $37 / 51$ & $82 / 46$ & $28 / 26$ & $108 / 73$ \\
\hline Diabetes (\%) & $20(42)$ & $29(33)$ & $47(37)$ & $16(30)$ & $66(37)$ \\
\hline DBP $(\mathrm{mmHg})$ & $80(20)$ & $80(20)$ & $80(17)$ & $80(20)$ & $75(15)^{2,3,4}$ \\
\hline WHR & $0.93(0.09)$ & $0.91(0.12)$ & $0.95(0.09)$ & $0.96(0.11)$ & $0 \cdot 97(0 \cdot 10)^{1,2,3}$ \\
\hline WHtR & $0.56(0 \cdot 10)$ & $0.59(0.12)$ & $0.60(0.09)$ & $0.59(0.09)$ & $0 \cdot 61(0 \cdot 13)^{1,2,3}$ \\
\hline Creatinine $(\mu \mathrm{mol} / \mathrm{l})$ & $59(19)$ & $80(23)$ & $139(43)^{1,2}$ & $217(70)^{1,2,3}$ & $702(392)^{1,2,3,4}$ \\
\hline $\operatorname{eGFR}\left(\mathrm{ml} / \mathrm{min} / 1.73 \mathrm{~m}^{2}\right)$ & $105 \cdot 2(12 \cdot 6)$ & $74 \cdot 7(13 \cdot 5)$ & $44 \cdot 1(14 \cdot 3)^{1,2}$ & $24 \cdot 5(5 \cdot 7)^{1,2,3}$ & $6 \cdot 7(5 \cdot 1)^{1,2,3,4}$ \\
\hline $\mathrm{FG}(\mathrm{mmol} / \mathrm{l})$ & $5 \cdot 5(2 \cdot 1)$ & $5 \cdot 5(1.4)$ & $5.7(1.9)$ & $5 \cdot 7(1 \cdot 4)$ & $4 \cdot 8(1 \cdot 8)^{1,2,3,4}$ \\
\hline Cholesterol (mmol/l) & $5 \cdot 3(1.5)$ & $5 \cdot 4(1 \cdot 3)$ & $5 \cdot 3(1 \cdot 6)$ & $6 \cdot 2(2 \cdot 4)$ & $4 \cdot 6(1 \cdot 7)^{1,2,3,4}$ \\
\hline HDL cholesterol $(\mathrm{mmol} / \mathrm{l})$ & $1.4(0.6)$ & $1 \cdot 4(0 \cdot 4)$ & $1.3(0.5)$ & $1.4(0.9)$ & $1 \cdot 1(0 \cdot 5)^{1,2,3,4}$ \\
\hline LDL cholesterol $(\mathrm{mmol} / \mathrm{l})$ & $3 \cdot 3(1.4)$ & $3 \cdot 3(1 \cdot 3)$ & $3.0(1.5)$ & $3 \cdot 1(1.9)$ & $2 \cdot 6(1 \cdot 3)^{1,2,3,4}$ \\
\hline hsCRP (mg/l) & $1.9(5 \cdot 1)$ & $2 \cdot 6(3 \cdot 7)$ & $2 \cdot 6(3 \cdot 3)$ & $3 \cdot 4(5 \cdot 0)$ & $4 \cdot 4(9 \cdot 6)^{1,2,3}$ \\
\hline hsIL-6 (ng/l) & $1.5(1.6)$ & $1.8(1.1)$ & $2.3(1.7)$ & $3 \cdot 1(3 \cdot 7)^{1,2,3}$ & $5 \cdot 0(5 \cdot 5)^{1,2,3,4}$ \\
\hline Leptin $(\mu \mathrm{g} / \mathrm{l})$ & $11 \cdot 5(15 \cdot 1)$ & $18 \cdot 3(26 \cdot 0)$ & $20 \cdot 3(36 \cdot 0)^{1}$ & $21.9(38 \cdot 7)^{1,2}$ & $19 \cdot 4(48 \cdot 1)^{1,2}$ \\
\hline Adiponectin (mg/l) & $5 \cdot 9(6 \cdot 5)$ & $6 \cdot 6(6 \cdot 9)$ & $9.0(8.6)$ & $10 \cdot 9(11 \cdot 0)^{1,2}$ & $15 \cdot 5(13 \cdot 8)^{1,2,3}$ \\
\hline
\end{tabular}

BMI, body mass index; CKD, chronic kidney disease; DBP, diastolic blood pressure; eGFR, estimated glomerular filtration rate; FG, fasting glucose; FGF-21, fibroblast growth factor-21; FI, fasting insulin; HDL, high-density lipoprotein; HOMA-IR, homeostasis model assessment of insulin resistance; hsCRP, high-sensitivity C-reactive protein; hsIL-6, high-sensitivity interleukin-6; LDL, low-density lipoprotein; SBP, systolic blood pressure; TG, triglycerides; WHR, waist-to-hip ratio; WHtR, waist-to-height ratio. Values for median (interquartile range) or total number (percentage) are shown. Continuous parameters were adjusted for age, gender and BMI and analysed by Kruskal-Wallis test followed by post-hoc analysis. Numbers in superscript indicate $P<0.05$ as compared to CKD stage $1,2,3$ or 4 . 
addition, patients with pre-existing CVD, that is coronary heart disease, chronic heart failure, stroke or peripheral arterial disease, had significantly higher FGF-21 concentrations (711.1 [1693.6] ng/l) as compared to subjects without CVD (400.9 $[941 \cdot 3] \mathrm{ng} / \mathrm{l})(P<0 \cdot 001)$.

Univariate correlations. Circulating FGF-21 was significantly and positively associated with age, WHR, WHtR, serum creatinine, TG, hsCRP, hsIL-6, leptin and adiponectin (Table 2). In contrast, FGF-21 serum concentrations in this population were significantly and negatively correlated with DBP, eGFR, FG, cholesterol, HDL cholesterol and LDL cholesterol (Table 2).

Multivariate regression analysis. After adjustment for age and gender, multivariate regression analysis of study population 1 revealed that serum FGF-21 levels remained strongly and negatively associated with eGFR independent of DBP, WHR, TG, HDL cholesterol, LDL cholesterol, hsIL-6 and adiponectin (Table 2). Furthermore, circulating FGF-21 remained negatively and independently associated with LDL cholesterol (Table 2). Moreover, an independent and positive association was observed

Table 2. Univariate correlations and multivariate regression analysis with serum FGF-21 in study population 1

\begin{tabular}{|c|c|c|c|c|}
\hline & \multicolumn{2}{|c|}{$\begin{array}{l}\text { Univariate } \\
\text { correlations }\end{array}$} & \multicolumn{2}{|c|}{$\begin{array}{l}\text { Multivariate } \\
\text { regression analysis }\end{array}$} \\
\hline & $r$ & $P$ & B & $P$ \\
\hline Age (years) & $0 \cdot 116$ & $0 \cdot 010^{*}$ & $0 \cdot 032$ & $0 \cdot 296$ \\
\hline Gender & - & - & $0 \cdot 013$ & $0 \cdot 701$ \\
\hline BMI $\left(\mathrm{kg} / \mathrm{m}^{2}\right)$ & 0.029 & $0 \cdot 517$ & - & - \\
\hline $\mathrm{SBP}(\mathrm{mmHg})$ & -0.003 & $0 \cdot 950$ & - & - \\
\hline DBP (mmHg) & $-0 \cdot 172$ & $<0 \cdot 001^{\star}$ & $-0 \cdot 018$ & $0 \cdot 546$ \\
\hline WHR & $0 \cdot 314$ & $<0 \cdot 001^{\star}$ & $0 \cdot 153$ & $<0 \cdot 001^{\dagger}$ \\
\hline WHtR & $0 \cdot 247$ & $<0 \cdot 001^{\star}$ & - & - \\
\hline Creatinine $(\mu \mathrm{mol} / \mathrm{l})$ & 0.719 & $<0 \cdot 001^{\star}$ & - & - \\
\hline eGFR $\left(\mathrm{ml} / \mathrm{min} / 1.73 \mathrm{~m}^{2}\right)$ & $-0 \cdot 727$ & $<0 \cdot 001^{\star}$ & -0.491 & $<0.001^{\dagger}$ \\
\hline $\mathrm{FG}(\mathrm{mmol} / \mathrm{l})$ & $-0 \cdot 107$ & $0 \cdot 018^{*}$ & - & - \\
\hline $\mathrm{FI}(\mathrm{pmol} / \mathrm{l})$ & -0.032 & $0 \cdot 476$ & - & - \\
\hline HOMA-IR & -0.057 & $0 \cdot 206$ & - & - \\
\hline TG (mmol/l) & $0 \cdot 291$ & $<0 \cdot 001^{\star}$ & $0 \cdot 193$ & $<0.001^{\dagger}$ \\
\hline Cholesterol (mmol/l) & $-0 \cdot 244$ & $<0.001^{\star}$ & - & - \\
\hline HDL cholesterol (mmol/l) & $-0 \cdot 340$ & $<0 \cdot 001^{\star}$ & 0.026 & $0 \cdot 525$ \\
\hline LDL cholesterol $(\mathrm{mmol} / \mathrm{l})$ & $-0 \cdot 298$ & $<0.001^{\star}$ & -0.084 & $0.009^{\dagger}$ \\
\hline $\mathrm{hsCRP}(\mathrm{mg} / \mathrm{l})$ & $0 \cdot 322$ & $<0 \cdot 001^{\star}$ & & \\
\hline hsIL-6 (ng/l) & $0 \cdot 564$ & $<0.001^{\star}$ & $0 \cdot 210$ & $<0.001^{\dagger}$ \\
\hline Leptin $(\mu \mathrm{g} / \mathrm{l})$ & $0 \cdot 124$ & $0 \cdot 006^{\star}$ & - & - \\
\hline Adiponectin (mg/l) & $0 \cdot 247$ & $<0 \cdot 001^{\star}$ & 0.065 & $0 \cdot 088$ \\
\hline
\end{tabular}

Multivariate regression analysis of FGF-21 (dependent variable) adjusted for age and gender, as well as DBP, WHR, eGFR, TG, HDL cholesterol, LDL cholesterol, hsIL-6 and adiponectin. Non-normally distributed variables were logarithmically transformed prior to multivariate testing. $r$ - and $P$-values, as well as standardized $B$-coefficients and $P$-values, are given. Abbreviations are indicated in Table 1. ${ }^{*}$ indicates significant correlation as assessed by Spearman's rank correlation method. $\dagger$ indicates significant correlation in multivariate analysis. between FGF-21 on one hand and WHR, TG and hsIL-6 on the other hand (Table 2). In addition, results were virtually identical when statin treatment or pre-existing CVD was included as additional covariates in the multivariate model (data not shown). It is interesting to note that statin treatment but not pre-existing CVD was an independent predictor of circulating FGF-21 (data not shown). Furthermore, WHtR and hsCRP were significant and positive predictors of circulating FGF-21 when included in the model instead of WHR and hsIL-6, respectively (data not shown).

\section{Study population 2}

FGF-21 serum levels are increased in patients after unilateral partial or total nephrectomy. Table 3 summarizes baseline characteristics of study population 2, as well as laboratory parameters before and after nephrectomy. FGF-21 serum levels were significantly increased in patients after unilateral partial or total nephrectomy $(325.0 \quad[984.0] \quad \mathrm{ng} / \mathrm{l})$ as compared to presurgical concentrations $(255.5 \quad[243.0] \quad \mathrm{ng} / \mathrm{l}) \quad(P<0.001)$ (Table 3). Furthermore, creatinine hsCRP and hsIL-6 were

Table 3. Baseline characteristics of study population 2 and serum parameters before and after renal surgery

\begin{tabular}{|c|c|c|c|}
\hline & & \multicolumn{2}{|c|}{ Baseline characteristics } \\
\hline$N$ & & 32 & \\
\hline Age (years) & & $63 \cdot 0(12 \cdot 8)$ & \\
\hline Gender $(\mathrm{m} / \mathrm{f})$ & & $26 / 6$ & \\
\hline Diabetes (\%) & & $6(19)$ & \\
\hline BMI $\left(\mathrm{kg} / \mathrm{m}^{2}\right)$ & & $26 \cdot 2(4 \cdot 9)$ & \\
\hline SBP (mmHg) & & $130(13)$ & \\
\hline DBP (mmHg) & & $85(10)$ & \\
\hline WHR & & $0.97(0 \cdot 12)$ & \\
\hline WHtR & & $0.56(0.07)$ & \\
\hline \multirow{2}{*}{$\begin{array}{l}\text { Time interval between } \\
\text { blood samplings }(\mathrm{h})\end{array}$} & & $20 \cdot 8(4 \cdot 0)$ & \\
\hline & Presurgery & Postsurgery & $P$ \\
\hline FGF-21 & $255 \cdot 5(243 \cdot 0)$ & $325 \cdot 0(984 \cdot 0)$ & $<0 \cdot 001^{*}$ \\
\hline Creatinine $(\mu \mathrm{mol} / \mathrm{l})$ & $86(33)$ & $96(44)$ & $0.001^{*}$ \\
\hline eGFR $\left(\mathrm{ml} / \mathrm{min} / 1.73 \mathrm{~m}^{2}\right)$ & $80 \cdot 1(20 \cdot 4)$ & $63.4(31.9)$ & $0.001^{*}$ \\
\hline FG $(\mathrm{mmol} / \mathrm{l})$ & $5.5(1.2)$ & $4.8(3.6)$ & $0 \cdot 160$ \\
\hline $\mathrm{FI}(\mathrm{pmol} / \mathrm{l})$ & $27 \cdot 1(40 \cdot 6)$ & $34 \cdot 3(42 \cdot 0)$ & 0.062 \\
\hline HOMA-IR & $0.9(1.4)$ & $1 \cdot 1(2 \cdot 4)$ & $0 \cdot 190$ \\
\hline TG (mmol/l) & $1.59(0.74)$ & $1 \cdot 16(0 \cdot 51)$ & $<0 \cdot 001^{*}$ \\
\hline Cholesterol (mmol/l) & $5 \cdot 1(1 \cdot 4)$ & $4 \cdot 2(1 \cdot 0)$ & $<0 \cdot 001^{*}$ \\
\hline HDL cholesterol $(\mathrm{mmol} / \mathrm{l})$ & $1 \cdot 1(0 \cdot 5)$ & $1.0(0 \cdot 4)$ & $0.037^{*}$ \\
\hline LDL cholesterol $(\mathrm{mmol} / \mathrm{l})$ & $3.4(1.4)$ & $2 \cdot 6(1 \cdot 0)$ & $<0 \cdot 001^{*}$ \\
\hline hsCRP (mg/l) & $2 \cdot 0(8 \cdot 4)$ & $34 \cdot 9(44 \cdot 8)$ & $<0 \cdot 001^{*}$ \\
\hline hsIL-6 (ng/l) & $1.4(2 \cdot 4)$ & $12 \cdot 0(6 \cdot 7)$ & $<0 \cdot 001^{*}$ \\
\hline Leptin $(\mu \mathrm{g} / \mathrm{l})$ & $3 \cdot 4(5 \cdot 8)$ & $3 \cdot 0(5 \cdot 8)$ & $0 \cdot 903$ \\
\hline Adiponectin (mg/l) & $5 \cdot 8(5 \cdot 4)$ & $5 \cdot 0(3 \cdot 0)$ & $<0 \cdot 001^{*}$ \\
\hline
\end{tabular}

Abbreviations are indicated in Table 1. Values for median (interquartile range) or total number (percentage) are shown. ${ }^{*}$ indicates $P<0.05$ as compared to presurgical values as assessed by Wilcoxon signed-rank test. 
significantly increased in patients after renal surgery, whereas eGFR, TG, cholesterol, HDL cholesterol, LDL cholesterol and adiponectin decreased significantly (Table 3 ).

Univariate correlations. Relative changes (postsurgical-topresurgical ratios) in FGF-21 levels were positively and signif icantly correlated with creatinine (ratio) (Table 4). Furthermore, eGFR (ratio) was negatively and significantly associated with FGF-21 (ratio) (Table 4).

Multivariate regression analysis. Even after adjustment for age and gender, FGF-21 (ratio) remained positively associated with creatinine (ratio) in multivariate regression analysis (Table 4). In addition, results were virtually the same when hsCRP or hsIL-6 were included as markers of inflammation in the multivariate model (data not shown).

\section{Discussion}

In the present study, we demonstrate that FGF-21 levels increase with deteriorating renal function in a large $(n=499)$ cohort

Table 4. Univariate correlations with relative changes in FGF-21 (postsurgical-to-presurgical ratio) before and after renal surgery and multivariate regression analysis of FGF-21 (ratio)

\begin{tabular}{|c|c|c|c|c|}
\hline & \multicolumn{2}{|c|}{$\begin{array}{l}\text { Univariate } \\
\text { correlations }\end{array}$} & \multicolumn{2}{|c|}{$\begin{array}{l}\text { Multivariate } \\
\text { regression analysis }\end{array}$} \\
\hline & $r$ & $P$ & B & $P$ \\
\hline Age (years) & $-0 \cdot 139$ & $0 \cdot 448$ & $-0 \cdot 354$ & $0.027^{\dagger}$ \\
\hline Gender & - & - & $0 \cdot 046$ & $0 \cdot 762$ \\
\hline BMI $\left(\mathrm{kg} / \mathrm{m}^{2}\right)$ & $0 \cdot 010$ & 0.957 & - & - \\
\hline SBP (mmHg) & -0.023 & 0.906 & - & - \\
\hline DBP (mmHg) & $-0 \cdot 293$ & $0 \cdot 123$ & - & - \\
\hline WHR & $-0 \cdot 023$ & $0 \cdot 905$ & - & - \\
\hline WHtR & -0.086 & 0.651 & - & - \\
\hline $\begin{array}{l}\text { Time interval between } \\
\text { blood samplings }(\mathrm{h})\end{array}$ & $0 \cdot 165$ & $0 \cdot 374$ & - & - \\
\hline Creatinine (ratio) & $0 \cdot 575$ & $0 \cdot 001^{*}$ & 0.623 & $<0 \cdot 001^{\dagger}$ \\
\hline eGFR (ratio) & $-0 \cdot 547$ & $0 \cdot 001^{*}$ & - & - \\
\hline FG (ratio) & $-0 \cdot 280$ & $0 \cdot 121$ & - & - \\
\hline FI (ratio) & $-0 \cdot 046$ & $0 \cdot 803$ & - & - \\
\hline HOMA-IR (ratio) & $-0 \cdot 127$ & $0 \cdot 488$ & - & - \\
\hline TG (ratio) & $-0 \cdot 168$ & $0 \cdot 358$ & - & - \\
\hline Cholesterol (ratio) & $0 \cdot 129$ & $0 \cdot 482$ & - & - \\
\hline HDL cholesterol (ratio) & $0 \cdot 103$ & $0 \cdot 575$ & - & - \\
\hline LDL cholesterol (ratio) & $0 \cdot 104$ & $0 \cdot 571$ & - & - \\
\hline hsCRP (ratio) & $-0 \cdot 109$ & $0 \cdot 554$ & - & - \\
\hline hsIL-6 (ratio) & $0 \cdot 008$ & 0.965 & - & - \\
\hline Leptin (ratio) & $-0 \cdot 008$ & 0.964 & - & - \\
\hline Adiponectin (ratio) & $0 \cdot 000$ & $0 \cdot 998$ & - & - \\
\hline
\end{tabular}

Multivariate regression analysis of FGF-21 (ratio, dependent variable) and age, gender, as well as creatinine (ratio) in all patients. Non-normally distributed variables were logarithmically transformed prior to multivariate testing. $r$ - and $P$-values, as well as standardized $B$-coefficients and $P$-values, are given. Abbreviations are indicated in Table 1. * indicates significant correlation as assessed by Spearman's rank correlation method. $\dagger$ indicates significant correlation in multivariate analysis. covering the whole spectrum of CKD stages (study population 1) for the first time. Furthermore, renal function is the strongest independent predictor of FGF-21 in this cohort. Moreover, we show that the adipokine is significantly and acutely upregulated in patients after unilateral partial or total nephrectomy (study population 2), a model for AKD. ${ }^{13,14}$ Interestingly, relative changes of FGF-21 (postsurgical-to-presurgical ratio) are positively and independently associated with relative changes in creatinine (postsurgical-to-presurgical ratio) in this cohort. These findings support the hypothesis that renal excretion is a major route for eliminating FGF-21 from circulation. It needs to be pointed out that median time at blood sampling is not the same for the presurgical and postsurgical measurements. Therefore, an effect of circadian rhythm on our results cannot be excluded with certainty; however, FGF-21 concentrations at both time points are similar according to evidence published by $\mathrm{Yu}$ et al. ${ }^{20}$ Furthermore, circulating FGF-21 does not appear to be dialyzable as it is significantly higher after as compared to before haemodialysis (data not shown).

Our findings suggest that markers of renal function, for example creatinine or eGFR, should be included in all studies on FGF-21 physiology. In agreement with our present findings, we ${ }^{6}$ and others ${ }^{7}$ have recently shown upregulation of circulating FGF-21 in end-stage renal disease. Furthermore, Lin et al. ${ }^{8} \mathrm{dem}-$ onstrate significantly increased FGF-21 levels in patients with severe CKD as compared to mild CKD and controls. Animal studies are necessary to elucidate which mechanisms contribute to renal elimination of FGF-21 and to determine the physiological relevance of increased FGF-21 levels in acute and chronic renal dysfunction.

Animal experiments demonstrate convincingly that FGF-21 is an insulin-sensitizing and lipid-lowering adipokine which increases energy expenditure. ${ }^{3}$ Thus, Sarruf et al. ${ }^{3}$ have recently shown that intracerebroventricular administration of FGF-21 in obese rats results in improved hepatic insulin sensitivity through suppression of hepatic glucose production and gluconeogenic gene expression. In agreement with these findings, Kharitonenkov et al. ${ }^{2}$ reveal that FGF-21 transgenic mice are resistant to diet-induced obesity. Most interestingly, FGF-21 increases adiponectin secretion in rodents in a very recent paper by Holland et $a .^{21}$ In more detail, administration of FGF-21 to obese wildtype mice results in extensive weight loss and improved glucose homeostasis. ${ }^{21}$ In contrast, these beneficial effects are not observed in obese adiponectin knockout mice suggesting adiponectin-dependent FGF-21 action in rodents. ${ }^{21}$ In our study population 1, FGF-21 shows a positive correlation with adiponectin in univariate analysis and a trend towards an independent positive association in multivariate analysis supporting the hypothesis that upregulation of adiponectin is FGF-21-mediated. Furthermore, administration of FGF-21 in diabetic primates results in a significant decline of fasting plasma glucose, as well as decreased TG and LDL cholesterol levels. ${ }^{22}$ Moreover, Coskun et $a .^{23}$ show convincingly that FGF-21-treated obese mice exhibit increased energy expenditure, fat utilization and lipid excretion. Taking these findings into consideration, it is tempting to speculate that increased circulating FGF- 21 in acute and chronic 
renal dysfunction might limit the adverse metabolic and vascular effects of the disease. Alternatively, FGF-21 resistance might be present in acute and chronic renal dysfunction similar to insulin resistance seen in obesity. ${ }^{24}$ It is interesting to note in this context that FGF-21 resistance has already been described in obesity. ${ }^{25}$ In more detail, Fisher et al. ${ }^{25}$ show convincingly that FGF21 mRNA expression increases in the liver and in white adipose tissue of obese mice. Furthermore, activation of the FGF-21 signalling pathways and FGF-21 mediated early gene transcription is impaired in obese mice. ${ }^{25}$ Clearly, more mechanistic studies are needed to better elucidate the physiological role of increased FGF-21 in acute and chronic kidney dysfunction.

In accordance with results obtained in obese rodents, we show a strong, positive and independent correlation between serum FGF-21 levels and WHR as a marker of adverse fat distribution in study population 1 . This is in accordance with a study by Zhang et al. $^{26}$ They reveal a positive association between FGF-21 levels and WHR even after adjustment for age and BMI in their study comprising 232 subjects. ${ }^{26}$ Similarly, FGF-21 is positively and independently correlated with WHtR in the present study which is an alternative marker for adverse body fat distribution. Interestingly, FGF-21 is not significantly associated with BMI and is not different between overweight/obese patients as compared to lean subjects. Because WHR and WHtR better reflect adverse body fat distribution as compared to $\mathrm{BMI},{ }^{27,28}$ it is tempting to speculate that an accumulation of visceral fat rather than increased body fat mass leads to a FGF-21 resistant state. Clearly, future studies are needed to determine the pathophysiological significance of FGF-21 upregulation/resistance in metabolic diseases.

In study population 1, FGF-21 correlates positively and independently with further markers of the MetS including TG and hsCRP similar to other reports. ${ }^{29,30}$ In contrast to other studies, ${ }^{29,31}$ FGF-21 does not correlate with measures of insulin resistance including FI and HOMA-IR. Interestingly, LDL cholesterol correlates paradoxically and negatively with circulating FGF-21 in study population 1 in multivariate analyses. These data are in accordance with a recent study from our group in pregnant women. ${ }^{32}$ It is interesting to note in this context that FGF-21 increases LDL-receptor expression in cultured human hepatocytes leading to an enhanced lipoprotein uptake. ${ }^{33}$ However, it needs to be pointed out that other data suggest a positive association between LDL cholesterol and FGF-21 levels in contrast to our findings. ${ }^{34}$ Differences in patient characteristics with regard to age, gender, renal function, ethnicity and phenotyping might well explain the different findings.

In contrast to FGF-21, adiponectin levels significantly decline after unilateral nephrectomy. Decreased adiponectin levels after surgery are paradoxical as its secretion is stimulated by FGF$21^{21}$, and its renal clearance is likely to be reduced postoperatively. ${ }^{35}$ Clearly, the causes for this unexpected regulation need to be elucidated in future studies.

There are some limitations of the study that need to be emphasized. First, a cross-sectional design is used for study population 1, and therefore, causality cannot be established. Second, the sample size of study population 2 is rather small, and it is quite possible that various nonsignificant associations in multivariate analyses would have become statistically significant if larger samples were studied. Third, we cannot exclude the possibility that confounding factors that influence circulating FGF-21 have not been considered. Fourth, no information is available in the present study concerning specific FGF receptors and $\beta$-klotho in target tissues through which biologically active FGF-21 acts.

Taken together, we demonstrate for the first time that circulating FGF-21 is increased in both CKD and AKD. Our results support the hypothesis that renal excretion is a major route to eliminate FGF-21 from circulation. The pathophysiological significance of these findings needs to be elucidated in more detail.

\section{Author contributions}

J.H., T.E. and M.F. wrote the manuscript and researched data. A.B., J.K., JU. S., A.D., J.B., M.A and I.B. researched data and reviewed/edited the manuscript. U.L. researched data. S.K. reviewed/edited the manuscript. M.B. and M.S. contributed to the discussion and reviewed/edited the manuscript. Guarantor: Dr Thomas Ebert is the guarantor of this work and, as such, had full access to all the data in the study and takes responsibility for the integrity of the data and the accuracy of the data analysis.

\section{Acknowledgements}

This study was supported by grants to M.F. from the Deutsche Forschungsgemeinschaft (DFG, SFB 1052/1, C06), the Federal Ministry of Education and Research (BMBF), Germany, FKZ: 01EO1001 (IFB AdiposityDiseases, projects K7-3, K7-9, and K731) and the Deutsche Hochdruckliga e.V. Furthermore, T.E. and J.H were supported by the Federal Ministry of Education and Research (BMBF), Germany, FKZ: 01EO1001 (IFB AdiposityDiseases, MetaRot/MD Pro 2 program). Moreover, T.E. was supported by a junior research grant by the Medical Faculty, University of Leipzig and a MSD grant (MSD Stipendium 2013 Diabetologie).

\section{Conflict of interests/financial disclosure}

Nothing to declare.

\section{References}

1 Hajer, G.R., van Haeften, T.W. \& Visseren, F.L.J. (2008) Adipose tissue dysfunction in obesity, diabetes, and vascular diseases. European Heart Journal, 29, 2959-2971.

2 Kharitonenkov, A., Shiyanova, T.L., Koester, A. et al. (2005) FGF-21 as a novel metabolic regulator. Journal of Clinical Investigation, 115, 1627-1635.

3 Sarruf, D.A., Thaler, J.P., Morton, G.J. et al. (2010) Fibroblast growth factor 21 action in the brain increases energy expenditure and insulin sensitivity in obese rats. Diabetes, 59, 1817-1824.

4 Lin, Z., Wu, Z., Yin, X. et al. (2010) Serum levels of FGF-21 are increased in coronary heart disease patients and are independently associated with adverse lipid profile. PLOS ONE, 5, e15534. 
5 Chavez, A.O., Molina-Carrion, M., Abdul-Ghani, M.A. et al. (2009) Circulating fibroblast growth factor-21 is elevated in impaired glucose tolerance and type 2 diabetes and correlates with muscle and hepatic insulin resistance. Diabetes Care, 32, 1542-1546.

6 Stein, S., Bachmann, A., Lössner, U. et al. (2009) Serum levels of the adipokine FGF21 depend on renal function. Diabetes Care, 32, 126-128.

7 Han, S.H., Choi, S.H., Cho, B.J. et al. (2010) Serum fibroblast growth factor-21 concentration is associated with residual renal function and insulin resistance in end-stage renal disease patients receiving long-term peritoneal dialysis. Metabolism, 59, 16561662.

8 Lin, Z., Zhou, Z., Liu, Y. et al. (2011) Circulating FGF21 levels are progressively increased from the early to end stages of chronic kidney diseases and are associated with renal function in Chinese. PLOS ONE, 6, e18398.

9 Richter, J., Focke, D., Ebert, T. et al. (2013) Serum levels of the adipokine progranulin depend on renal function. Diabetes Care, 36, 410-414.

10 Levey, A.S., Bosch, J.P., Lewis, J.B. et al. (1999) A more accurate method to estimate glomerular filtration rate from serum creatinine: a new prediction equation. Annals of Internal Medicine, 130, 461-470.

11 Levey, A.S., Coresh, J., Balk, E. et al. (2003) National kidney foundation practice guidelines for chronic kidney disease: evaluation, classification, and stratification. Annals of Internal Medicine, 139, 137-147.

12 Matthews, D.R., Hosker, J.P., Rudenski, A.S. et al. (1985) Homeostasis model assessment: insulin resistance and beta-cell function from fasting plasma glucose and insulin concentrations in man. Diabetologia, 28, 412-419.

13 Siebels, M., Theodorakis, J., Schmeller, N. et al. (2003) Risks and complications in 160 living kidney donors who underwent nephroureterectomy. Nephrology Dialysis Transplantation, 18, 26482654.

14 Argiles, A., Mourad, G., Basset, N. et al. (1987) Acute adaptative changes to unilateral nephrectomy in humans. Kidney International, 32, 714-720.

15 Richter, J., Ebert, T., Stolzenburg, J.-U. et al. (2013) Response to comment on: Richter et al. Serum levels of the adipokine progranulin depend on renal function. Diabetes Care 2013;36:410-414. Diabetes Care, 36, e84.

16 Levey, A.S., Stevens, L.A., Schmid, C.H. et al. (2009) A new equation to estimate glomerular filtration rate. Annals of Internal Medicine, 150, 604-612.

17 Zhang, M.H., Spies, C., Ali, S. et al. (2009) Adiponectin and inducible ischemia in patients with stable coronary heart disease: data from the Heart and Soul study. Atherosclerosis, 205, 233-238.

18 Li, S., Shin, H., Ding, E.L. et al. (2009) Adiponectin levels and risk of type 2 diabetes: a systematic review and meta-analysis. JAMA, 302, 179-188.

19 Almagor, M., Mintz, A., Sibirsky, O. et al. (2005) Preoperative and postoperative levels of interleukin- 6 in patients with acute appendicitis: comparison between open and laparoscopic appendectomy. Surgical Endoscopy and Other Interventional Techniques, 19, 331-333.

20 Yu, H., Xia, F., Lam, K.S.L. et al. (2011) Circadian rhythm of circulating fibroblast growth factor 21 is related to diurnal changes in fatty acids in humans. Clinical Chemistry, 57, 691700 .

21 Holland, W.L., Adams, A.C., Brozinick, J.T. et al. (2013) An FGF21-adiponectin-ceramide axis controls energy expenditure and insulin action in mice. Cell Metabolism, 17, 790-797.

22 Kharitonenkov, A., Wroblewski, V.J., Koester, A. et al. (2007) The metabolic state of diabetic monkeys is regulated by fibroblast growth factor-21. Endocrinology, 148, 774-781.

23 Coskun, T., Bina, H.A., Schneider, M.A. et al. (2008) Fibroblast growth factor 21 corrects obesity in mice. Endocrinology, 149, 6018-6027.

24 Kahn, B.B. \& Flier, J.S. (2000) Obesity and insulin resistance. Journal of Clinical Investigation, 106, 473-481.

25 Fisher, F.M., Chui, P.C., Antonellis, P.J. et al. (2010) Obesity is a fibroblast growth factor 21 (FGF21)-resistant state. Diabetes, 59, 2781-2789.

26 Zhang, X., Yeung, D.C.Y., Karpisek, M. et al. (2008) Serum FGF21 levels are increased in obesity and are independently associated with the metabolic syndrome in humans. Diabetes, 57, 1246-1253.

27 Yusuf, S., Hawken, S., Ônpuu, S. et al. (2005) Obesity and the risk of myocardial infarction in 27,000 participants from 52 countries: a case-control study. The Lancet, 366, 1640-1649.

28 Ashwell, M., Cole, T.J. \& Dixon, A.K. (1996) Ratio of waist circumference to height is strong predictor of intra-abdominal fat. British Medical Journal, 313, 559-560.

29 Lee, Y., Lim, S., Hong, E.-S. et al. (2014) Serum FGF21 concentration is associated with hypertriglyceridaemia, hyperinsulinaemia and pericardial fat accumulation, independently of obesity, but not with current coronary artery status. Clinical Endocrinology, 80, 57-64.

30 Li, X., Fan, X., Ren, F. et al. (2011) Serum FGF21 levels are increased in newly diagnosed type 2 diabetes with nonalcoholic fatty liver disease and associated with hsCRP levels independently. Diabetes Research and Clinical Practice, 93, 10-16.

31 Stein, S., Stepan, H., Kratzsch, J. et al. (2010) Serum fibroblast growth factor 21 levels in gestational diabetes mellitus in relation to insulin resistance and dyslipidemia. Metabolism, 59, 33-37.

32 Stepan, H., Kley, K., Hindricks, J. et al. (2013) Serum levels of the adipokine fibroblast growth factor-21 are increased in preeclampsia. Cytokine, 62, 322-326.

33 Do, H.T., Tselykh, T.V., Mäkelä, J. et al. (2012) Fibroblast growth factor-21 (FGF21) regulates low-density lipoprotein receptor (LDLR) levels in cells via the E3-ubiquitin ligase Mylip/ Idol and the Canopy2 (Cnpy2)/Mylip-interacting saposin-like protein (Msap). Journal of Biological Chemistry, 287, 1260212611.

34 Chen, C., Cheung, B.M.Y., Tso, A.W.K. et al. (2011) High plasma level of fibroblast growth factor 21 is an independent predictor of type 2 diabetes a 5.4-year population-based prospective study in Chinese subjects. Diabetes Care, 34, 2113-2115.

35 Kotulák, T., Drápalová, J., Kopecký, P. et al. (2011) Increased circulating and epicardial adipose tissue mRNA expression of fibroblast growth factor- 21 after cardiac surgery: possible role in postoperative inflammatory response and insulin resistance. Physiological Research/Academia Scientiarum Bohemoslovaca, 60, 757-767. 


\section{Abstract}

Dissertation submitted in partial fulfillment of the requirements for the degree of Dr. med.

Serum levels of fibroblast growth factor-21 are increased in chronic and acute renal dysfunction

submitted by

Janka Hindricks, born August 05 ${ }^{\text {th }}, 1986$

prepared at the

Klinik und Poliklinik für Endokrinologie und Nephrologie, Universität Leipzig

mentored by

Prof. Dr. med. habil. Mathias Faßhauer

Submission August 2014

The prevalence of the Metabolic Syndrome (MetS) has been increasing globally for the past decades and the prevalence in Germany is above $20 \%$. The MetS is associated with an increased risk for cardiovascular morbidity and mortality. According to the NCEP definition, key aspects of the MetS include increases in serum lipids, elevated blood pressure, hyperglycemia, as well as central obesity. Out of these components, central obesity shows the strongest association with the MetS and weight loss therapy improves all MetS aspects, as well as its comorbidities. The development of central obesity usually occurs alongside with an increase in central adipose tissue mass. Adipose tissue functions as a complex endocrine organ and endocrine networks are dysregulated in obese patients. Adipose tissue produces a multitude of proteins - so-called adipokines - with various effects on human metabolism. These adipokines provide a potential link between body mass and the occurrence of metabolic disturbances.

In this context, FGF-21, a novel adipokine with beneficial effects on glucose and lipid profile in rodents, has been subject to thorough investigation. FGF-21 stimulates glucose uptake in preadipocytes independent from insulin. Furthermore, administration of the adipokine reduces body weight and improves insulin sensitivity in rodents and primates. In humans, FGF-21 levels are dysregulated in different metabolic disease states. Thus, FGF-21 concentrations are 
elevated in patients with T2DM. In accordance with these findings, obese patients exhibit increased levels of the adipokine and the number of manifested MetS components predicts FGF-21 concentrations. A FGF-21-resistant state has been implied to be partially accountable for these findings. Despite extensive studies on FGF-21 regulation in human metabolic disease, data on FGF-21 elimination were rather limited.

Therefore, the relation between the adipokine and human renal function in patients with chronic kidney disease (study population 1) and acute renal impairment (study population 2) has been investigated in the context of this dissertation. The adipokine was quantified in venous blood samples by commercial enzyme linked immunosorbent assay and correlated to anthropometric and biochemical markers of renal function, glucose and lipid homeostasis, as well as inflammation.

Study population $1(\mathrm{n}=499)$ was divided into 5 groups representing CKD stages 1 to 5 according to the KDOQI criteria. Median FGF-21 serum levels progressively increased from stage 1 to 5 (1: $86.4 \mathrm{ng} / 1 ; 2: 206.4 \mathrm{ng} / 1 ; 3: 289.8 \mathrm{ng} / 1 ; 4: 591.3 \mathrm{ng} / 1 ; 5: 1918.1 \mathrm{ng} / \mathrm{l})$ while renal function assessed as eGFR progressively declined. In multivariate analysis, eGFR remained the strongest predictor for FGF-21 levels $(\mathrm{p}<0.001)$.

In study population $2(\mathrm{n}=32)$ FGF-21 levels were quantified in patients undergoing unilateral partial or total nephrectomy shortly before surgery, and again within 30 hours after surgery. Median FGF-21 levels significantly increased after (325.0 ng/l) as compared to before surgery (255.5 ng/1; $\mathrm{p}<0.001)$. Furthermore, relative changes of FGF-21 were independently and positively predicted by relative changes of creatinine in this cohort $(\mathrm{p}<0.001)$.

Taken together, these results further support a strong relation between the adipokine FGF-21 and chronic renal dysfunction. Furthermore, first data regarding increased FGF-21 levels in acute kidney injury are presented. Our results are in accordance with the hypothesis that renal elimination of the adipokine is a major contributor to FGF-21 physiology. Animal studies are needed in order to further elucidate the role of elevated FGF-21 levels in kidney dysfunction and to define the extent to which serum FGF-21 elevation contributes to kidney disease comorbidities. 


\section{References}

1. Ford E.S., Giles W.H., \& Mokdad A.H. (2004) Increasing Prevalence of the Metabolic Syndrome Among U.S. Adults. Diabetes Care, 27, 2444-9.

2. Moebus S., Hanisch J.U., Aidelsburger P. et al. (2007) Impact of 4 different definitions used for the assessment of the prevalence of the Metabolic Syndrome in primary healthcare: The German Metabolic and Cardiovascular Risk Project (GEMCAS). Cardiovascular diabetology, 6, 22.

3. Hansen B.C. (1999) The Metabolic Syndrome X. Annals of the New York Academy of Sciences, 892, 1-24.

4. Kaplan N.M. (1989) The deadly quartet. Upper-body obesity, glucose intolerance, hypertriglyceridemia, and hypertension. Archives of internal medicine, 149, 1514-20.

5. Kylin E. (1923) Studien über das Hypertonie-Hyperglykämie-Hyperurikämiesyndrom. Zentralblatt für Innere Medizin;

6. Vague J. (1947). La différenciation sexuelle facteur déterminant des formes de l'obésité. La presse medicale;

7. Executive Summary of The Third Report of The National Cholesterol Education Program (NCEP) Expert Panel on Detection, Evaluation, And Treatment of High Blood Cholesterol In Adults (Adult Treatment Panel III) (2001). JAMA: the journal of the American Medical Association, 285, 2486-97.

8. Alberti K.G.M.M., \& Zimmet P. z. (1998) Definition, diagnosis and classification of diabetes mellitus and its complications. Part 1: diagnosis and classification of diabetes mellitus. Provisional report of a WHO Consultation. Diabetic Medicine, 15, 539-53.

9. Alberti K.G.M.M., Zimmet P., \& Shaw J. (2006) Metabolic syndrome--a new worldwide definition. A Consensus Statement from the International Diabetes Federation. Diabetic medicine: a journal of the British Diabetic Association, 23, 469-80.

10. Ford E.S. (2005) Risks for All-Cause Mortality, Cardiovascular Disease, and Diabetes Associated With the Metabolic Syndrome A summary of the evidence. Diabetes Care, 28, 1769-78.

11. Isomaa B., Almgren P., Tuomi T. et al. (2001) Cardiovascular Morbidity and Mortality Associated With the Metabolic Syndrome. Diabetes Care, 24, 683-9.

12. Lakka H.-M., Laaksonen D.E., Lakka T.A. et al. (2002) The metabolic syndrome and total and cardiovascular disease mortality in middle-aged men. JAMA: the journal of the American Medical Association, 288, 2709-16.

13. Grundy S.M., Brewer H.B., Cleeman J.I. et al. (2004) Definition of Metabolic Syndrome Report of the National Heart, Lung, and Blood Institute/American Heart Association Conference on Scientific Issues Related to Definition. Circulation, 109, 433-8.

14. Case C.C., Jones P.H., Nelson K. et al. (2002) Impact of weight loss on the metabolic syndrome. Diabetes, Obesity and Metabolism, 4, 407-14.

15. Kannel W.B., D'Agostino R.B., \& Cobb J.L. (1996) Effect of weight on c ardiovascular disease. The American Journal of Clinical Nutrition, 63, 419S-422S.

16. Clinical Guidelines on the Identification, Evaluation, and Treatment of Overweight and Obesity in Adults--The Evidence Report. National Institutes of Health. (1998) Obesity research, 6 Suppl 2, 51S-209S.

17. Pouliot M.C., Després J.P., Lemieux S. et al. (1994) Waist circumference and abdominal sagittal diameter: best simple anthropometric indexes of abdominal visceral adipose tissue accumulation and related cardiovascular risk in men and women. The American journal of cardiology, 73, 460-8.

18. Tilg H., \& Moschen A.R. (2006) Adipocytokines: mediators linking adipose tissue, inflammation and immunity. Nature reviews. Immunology, 6, 772-83. 
19. Rosen E.D., \& Spiegelman B.M. (2006) Adipocytes as regulators of energy balance and glucose homeostasis. Nature, 444, 847-53.

20. Lee Y.S., Morinaga H., Kim J.J. et al. (2013) The Fractalkine/CX3CR1 System Regulates $\beta$ Cell Function and Insulin Secretion. Cell, 153, 413-25.

21. Henry B.A., \& Clarke I.J. (2008) Adipose Tissue Hormones and the Regulation of Food Intake. Journal of Neuroendocrinology, 20, 842-9.

22. Ouchi N., Parker J.L., Lugus J.J. et al. (2011) Adipokines in inflammation and metabolic disease. Nature reviews. Immunology, 11, 85-97.

23. Ingalls A.M., Dickie M.M., \& Snell G.D. (1950) Obese, a new mutation in the house mouse. The Journal of heredity, 41, 317-8.

24. Zhang Y., Proenca R., Maffei M. et al. (1994) Positional cloning of the mouse obese gene and its human homologue. Nature, 372, 425-32.

25. Tartaglia L.A., Dembski M., Weng X. et al. (1995) Identification and expression cloning of a leptin receptor, OB-R. Cell, 83, 1263-71.

26. Stephens T.W., Basinski M., Bristow P.K. et al. (1995) The role of neuropeptide Y in the antiobesity action of the obese gene product. Nature, 377, 530-2.

27. Kieffer T.J., Heller R.S., \& Habener J.F. (1996) Leptin Receptors Expressed on Pancreatic $\beta$-Cells. Biochemical and Biophysical Research Communications, 224, 522-7.

28. Bornstein S.R., Abu-Asab M., Glasow A. et al. (2000) Immunohistochemical and ultrastructural localization of leptin and leptin receptor in human white adipose tissue and differentiating human adipose cells in primary culture. Diabetes, 49, 532-8.

29. Hoggard N., Hunter L., Duncan J.S. et al. (1997) Leptin and leptin receptor mRNA and protein expression in the murine fetus and placenta. Proceedings of the National Academy of Sciences, 94, 11073-8.

30. Jhanwar-Uniyal M., Beck B., Jhanwar Y.S. et al. (1993) Neuropeptide Y projection from arcuate nucleus to parvocellular division of paraventricular nucleus: specific relation to the ingestion of carbohydrate. Brain Research, 631, 97-106.

31. Pelleymounter M.A., Cullen M.J., Baker M.B. et al. (1995) Effects of the obese gene product on body weight regulation in ob/ob mice. Science (New York, N.Y.), 269, 5403.

32. Chiba T., Shinozaki S., Nakazawa T. et al. (2008) Leptin deficiency suppresses progression of atherosclerosis in apoE-deficient mice. Atherosclerosis, 196, 68-75.

33. Elefteriou F., Ahn J.D., Takeda S. et al. (2005) Leptin regulation of bone resorption by the sympathetic nervous system and CART. Nature, 434, 514-20.

34. Halaas J.L., Gajiwala K.S., Maffei M. et al. (1995) Weight-reducing effects of the plasma protein encoded by the obese gene. Science (New York, N.Y.), 269, 543-6.

35. Oral E.A., Simha V., Ruiz E. et al. (2002) Leptin-Replacement Therapy for Lipodystrophy. New England Journal of Medicine, 346, 570-8.

36. Lönnqvist F., Arner P., Nordfors L. et al. (1995) Overexpression of the obese (ob) gene in adipose tissue of human obese subjects. Nature Medicine, 1, 950-3.

37. Franks P.W., Brage S., Luan J. et al. (2005) Leptin predicts a worsening of the features of the metabolic syndrome independently of obesity. Obesity research, 13, 1476-84.

38. Maeda K., Okubo K., Shimomura I. et al. (1996) cDNA Cloning and Expression of a Novel Adipose Specific Collagen-like Factor, apM1 (dioseost Abundant Gene Transcript 1). Biochemical and Biophysical Research Communications, 221, 286-9.

39. Kadowaki T., \& Yamauchi T. (2005) Adiponectin and Adiponectin Receptors. Endocrine Reviews, 26, 439-51.

40. Fu Y., Luo N., Klein R.L. et al. (2005) Adiponectin promotes adipocyte differentiation, insulin sensitivity, and lipid accumulation. Journal of Lipid Research, 46, 1369-79. 
41. Bauche I.B., Mkadem S.A.E., Pottier A.-M. et al. (2007) Overexpression of Adiponectin Targeted to Adipose Tissue in Transgenic Mice: Impaired Adipocyte Differentiation. Endocrinology, 148, 1539-49.

42. Hu E., Liang P., \& Spiegelman B.M. (1996) AdipoQ Is a Novel Adipose-specific Gene Dysregulated in Obesity. Journal of Biological Chemistry, 271, 10697-703.

43. Maeda N., Shimomura I., Kishida K. et al. (2002) Diet-induced insulin resistance in mice lacking adiponectin/ACRP30. Nature Medicine, 8, 731-7.

44. Hotta K., Funahashi T., Bodkin N.L. et al. (2001) Circulating Concentrations of the Adipocyte Protein Adiponectin Are Decreased in Parallel With Reduced Insulin Sensitivity During the Progression to Type 2 Diabetes in Rhesus Monkeys. Diabetes, 50, 1126-33.

45. Hotta K., Funahashi T., Arita Y. et al. (2000) Plasma Concentrations of a Novel, Adipose-Specific Protein, Adiponectin, in Type 2 Diabetic Patients. Arteriosclerosis, Thrombosis, and Vascular Biology, 20, 1595-9.

46. Renaldi O., Pramono B., Sinorita H. et al. (2009) Hypoadiponectinemia: a risk factor f or metabolic syndrome. Acta medica Indonesiana, 41, 20-4.

47. Baden M.Y., Yamada Y., Takahi Y. et al. (2013) Association of adiponectin with blood pressure in healthy people. Clinical endocrinology, 78, 226-31.

48. Ouchi N., Kihara S., Arita Y. et al. (1999) Novel modulator for endothelial adhesion molecules: adipocyte-derived plasma protein adiponectin. Circulation, 100, 2473-6.

49. Nagpal S., Patel S., Asano A.T. et al. (1996) Tazarotene-induced gene 1 (TIG1), a novel retinoic acid receptor-responsive gene in skin. The Journal of investigative dermatology, 106, 269-74.

50. Ernst M.C., Issa M., Goralski K.B. et al. (2010) Chemerin exacerbates glucose intolerance in mouse models of obesity and diabetes. Endocrinology, 151, 1998-2007.

51. Wittamer V., Franssen J.-D., Vulcano M. et al. (2003) Specific Recruitment of Antigen-presenting Cells by Chemerin, a Novel Processed Ligand from Human Inflammatory Fluids. The Journal of Experimental Medicine, 198, 977-85.

52. Roh S., Song S.-H., Choi K.-C. et al. (2007) Chemerin-A new adipokine that modulates adipogenesis via its own receptor. Biochemical and Biophysical Research Communications, 362, 1013-8.

53. Takahashi M., Takahashi Y., Takahashi K. et al. (2008) Chemerin enhances insulin signaling and potentiates insulin-stimulated glucose uptake in 3T3-L1 adipocytes. FEBS letters, 582, 573-8.

54. Lehrke M., Becker A., Greif M. et al. (2009) Chemerin is associated with markers of inflammation and components of the metabolic syndrome but does not predict coronary atherosclerosis. European Journal of Endocrinology, 161, 339-44.

55. Spiroglou S.G., Kostopoulos C.G., Varakis J.N. et al. (2010) Adipokines in periaortic and epicardial adipose tissue: differential expression and relation to atherosclerosis. Journal of atherosclerosis and thrombosis, 17, 115-30.

56. Weigert J., Neumeier M., Wanninger J. et al. (2010) Systemic chemerin is related to inflammation rather than obesity in type 2 diabetes. Clinical endocrinology, 72, 3428.

57. Yang M., Yang G., Dong J. et al. (2010) Elevated plasma levels of chemerin in newly diagnosed type 2 diabetes mellitus with hypertension. Journal of investigative medicine: the official publication of the American Federation for Clinical Research, 58, 883-6.

58. Baird A., \& Walicke P.A. (1989) Fibroblast growth factors. British Medical Bulletin, 45, 438-52.

59. Gospodarowicz D. (1974) Localisation of a fibroblast growth factor and its effect alone and with hydrocortisone on 3 T3 cell growth. Nature, 249, 123-7. 
60. Itoh N., \& Ornitz D.M. (2008) Functional evolutionary history of the mouse Fgf gene family. Developmental dynamics: an official publication of the American Association of Anatomists, 237, 18-27.

61. Nishimura T., Nakatake Y., Konishi M. et al. (2000) Identification of a novel FGF, FGF-21, preferentially expressed in the liver. Biochimica et biophysica acta, 1492, 203-6.

62. Zhang X., Yeung D.C.Y., Karpisek M. et al. (2008) Serum FGF21 levels are increased in obesity and are independently associated with the metabolic syndrome in humans. Diabetes, 57, 1246-53.

63. Kharitonenkov A., Shiyanova T.L., Koester A. et al. (2005) FGF-21 as a novel metabolic regulator. Journal of Clinical Investigation, 115, 1627-35.

64. Ge X., Chen C., Hui X. et al. (2011) Fibroblast Growth Factor 21 Induces Glucose Transporter-1 Expression through Activation of the Serum Response Factor/Ets-Like Protein-1 in Adipocytes. The Journal of Biological Chemistry, 286, 34533-41.

65. Fisher F.M., Chui P.C., Antonellis P.J. et al. (2010) Obesity is a fibroblast growth factor 21 (FGF21)-resistant state. Diabetes, 59, 2781-9.

66. Xu J., Lloyd D.J., Hale C. et al. (2009) Fibroblast growth factor 21 reverses hepatic steatosis, increases energy expenditure, and improves insulin sensitivity in dietinduced obese mice. Diabetes, 58, 250-9.

67. Kharitonenkov A., Wroblewski V.J., Koester A. et al. (2007) The metabolic state of diabetic monkeys is regulated by fibroblast growth factor-21. Endocrinology, 148, 774-81.

68. Chavez A.O., Molina-Carrion M., Abdul-Ghani M.A. et al. (2009) Circulating fibroblast growth factor-21 is elevated in impaired glucose tolerance and type 2 diabetes and correlates with muscle and hepatic insulin resistance. Diabetes care, 32 , 1542-6.

69. Chen W.-W., Li L., Yang G.-Y. et al. (2008) Circulating FGF-21 levels in normal subjects and in newly diagnose patients with Type 2 diabetes mellitus. Experimental and clinical endocrinology \& diabetes: official journal, German Society of Endocrinology [and] German Diabetes Association, 116, 65-8.

70. Mraz M., Bartlova M., Lacinova Z. et al. (2009) Serum concentrations and tissue expression of a novel endocrine regulator fibroblast growth factor-21 in patients with type 2 diabetes and obesity. Clinical endocrinology, 71, 369-75.

71. Bobbert T., Schwarz F., Fischer-Rosinsky A. et al. (2013) Fibroblast Growth Factor 21 Predicts the Metabolic Syndrome and Type 2 Diabetes in Caucasians. Diabetes Care, 36, 145-9.

72. McCullough P.A., Li S., Jurkovitz C.T. et al. (2008) Chronic kidney disease, prevalence of premature cardiovascular disease, and relationship to short-term mortality. American Heart Journal, 156, 277-83.

73. Kundhal K., \& Lok C.E. (2005) Clinical epidemiology of cardiovascular disease in chronic kidney disease. Nephron. Clinical practice, 101, c47-52.

74. Axelsson J., Heimbürger O., \& Stenvinkel P. (2006). Adipose Tissue and Inflammation in Chronic Kidney Disease. Contributions to Nephrology, 151, 165-74

75. Cumin F., Baum H.P., \& Levens N. (1997) Mechanism of leptin removal from the circulation by the kidney. The Journal of endocrinology, 155, 577-85.

76. Sharma K., Considine R.V., Michael B. et al. (1997) Plasma leptin is partly cleared by the kidney and is elevated in hemodialysis patients. Kidney international, 51, 1980-5.

77. Nordfors L., Lönnqvist F., Heimbürger O. et al. (1998) Low leptin gene expression and hyperleptinemia in chronic renal failure. Kidney International, 54, 1267-75.

78. Schiffrin E.L., Lipman M.L., \& Mann J.F.E. (2007) Chronic Kidney Disease Effects on the Cardiovascular System. Circulation, 116, 85-97. 
79. Komura N., Kihara S., Sonoda M. et al. (2010) Increment and impairment of adiponectin in renal failure. Cardiovascular Research, 86, 471-7.

80. Chudek J., Adamczak M., Karkoszka H. et al. (2003) Plasma adiponectin concentration before and after successful kidney transplantation. Transplantation Proceedings, 35, 2186-9.

81. Becker B., Kronenberg F., Kielstein J.T. et al. (2005) Renal Insulin Resistance Syndrome, Adiponectin and Cardiovascular Events in Patients with Kidney Disease: The Mild and Moderate Kidney Disease Study. Journal of the American Society of Nephrology, 16, 1091-8.

82. Menon V., Li L., Wang X. et al. (2006) Adiponectin and Mortality in Patients with Chronic Kidney Disease. Journal of the American Society of Nephrology, 17, 2599606.

83. Pfau D., Bachmann A., Lössner U. et al. (2010) Serum Levels of the Adipokine Chemerin in Relation to Renal Function. Diabetes Care, 33, 171-3.

84. Yamamoto T., Qureshi A.R., Anderstam B. et al. (2010) Clinical importance of an elevated circulating chemerin level in incident dialysis patients. Nephrology Dialysis Transplantation, 25, 4017-23.

85. Rutkowski P., Sledzinski T., Zielinska H. et al. (2012) Decrease of serum chemerin concentration in patients with end stage renal disease after successful kidney transplantation. Regulatory Peptides, 173, 55-9.

86. Stein S., Bachmann A., Lössner U. et al. (2009) Serum levels of the adipokine FGF21 depend on renal function. Diabetes care, 32, 126-8.

87. Lin Z., Zhou Z., Liu Y. et al. (2011) Circulating FGF21 levels are progressively i ncreased from the early to end stages of chronic kidney diseases and are associated with renal function in Chinese. PloS one, 6, e18398. 


\section{A. Abbreviations}

CCRL2

Chemokine receptor-like 2

CKD

Chronic Kidney disease

CMKLR1 Chemokine receptor-like 1

CRP C-reactive protein

CVD Cardiovascular disease eGFR

ESRD lomerular filtration rate

FGF-21

GLUT-1 End-stage renal disease

GPR1

HDL hs

IL-6 ibroblast growth factor -21 Glucose transporter-1 G protein-coupled receptor 1 High density lipoprotein KDOQ High sensitivity

LDL Interleukin-6 Kidney disease quality outcome initiative

MetS Low density lipoprotein mRNA Metabolic Syndrome NCEP NPY Messenger ribonucleic acid $o b$ gene Neuropeptide $Y$ T2DM Obese gene TNF Type 2 diabetes mellitus WHR Tumor necrosis factor Waist-to-hip ratio 


\section{B. Erklärung über die eigenständige Abfassung der Arbeit}

Hiermit erkläre ich, dass ich die vorliegende Arbeit selbständig und ohne unzulässige Hilfe oder Benutzung anderer als der angegebenen Hilfsmittel angefertigt habe. Ich versichere, dass Dritte von mir weder unmittelbar noch mittelbar geldwerte Leistungen für Arbeiten erhalten haben, die im Zusammenhang mit dem Inhalt der vorgelegten Dissertation stehen, und dass die vorgelegte Arbeit weder im Inland noch im Ausland in gleicher oder ähnlicher Form einer anderen Prüfungsbehörde zum Zweck einer Promotion oder eines anderen Prüfungsverfahrens vorgelegt wurde. Alles aus anderen Quellen und von anderen Personen übernommene Material, das in der Arbeit verwendet wurde oder auf das direkt Bezug genommen wird, wurde als solches kenntlich gemacht. Insbesondere wurden alle Personen genannt, die direkt an der Entstehung der vorliegenden Arbeit beteiligt waren.

Datum

Unterschrift 


\section{Erklärung über die Vorbehaltlichkeit der Verfahrenseröffnung zur Verleihung des Titels Dr. med.}

Der erfolgreiche Abschluss des letzten Staatsexamens oder die Approbation zum Arzt ist Voraussetzung für den Abschluss des Promotionsverfahrens und damit der Verleihung des akademischen Grades. Die Zulassung zum Promotionsverfahren ist insoweit nur vorläufig und steht unter der auflösenden Bedingung des Nichtbestehens des letzten Staatsexamens oder der Approbation zum Arzt. Dieser Abschluss ersetzt nach Regelung im $\S 12$ der Promotionsordnung das Rigorosum. Das Rigorosum ist essentieller Bestandteil und notwendig zum erfolgreichen Abschluss des Promotionsverfahrens. Entsprechend den Regelungen in $\S 12$ wird das eröffnete Promotionsverfahren bei Nichtbeendigung des Studiums durch die Promotionskommission ohne Titelvergabe eingestellt.

Hiermit erkläre ich, dass mir dieser Sachverhalt im Rahmen der Eröffnung meines Promotionsverfahrens bekannt ist und ich im Falle des Fehlens der Voraussetzung des Abschlusses meines Promotionsverfahrens keine rechtlichen Ansprüche an eine Vergabe eines akademischen Grades oder Titels stelle. 
